\title{
Migratory songbirds in the East Asian-Australasian Flyway: a review from a conservation perspective
}

\author{
DING LI YONG, YANG LIU, BING WEN LOW, CARMELA P. ESPAÑOLA, \\ CHANG-YONG CHOI and KAZUTO KAWAKAMI
}

\section{Summary}

The East Asian-Australasian Flyway supports the greatest diversity and populations of migratory birds globally, as well as the highest number of threatened migratory species of any flyway, including passerines ( 15 species). However it is also one of the most poorly understood migration systems, and little is known about the populations and ecology of the passerine migrants that breed, stop over and winter in the habitats along this flyway. We provide the first flyway-wide review of diversity, ecology, and conservation issues relating to 170 species of long-distance and over 80 short-distance migrants from 32 families. Recent studies of songbird migration movements and ecology is limited, and is skewed towards East Asia, particularly Mainland China, Taiwan, Russia, Japan and South Korea. Strong evidence of declines exists for some species, e.g. Yellow-breasted Bunting Emberiza aureola, but tends to be fragmentary, localised or anecdotal for many others. More species have small breeding ranges $\left(<250,000 \mathrm{~km}^{2}\right)$ and/or are dependent on tropical forests as wintering habitat than those in any other Eurasian migratory system, and are thus more vulnerable to habitat loss and degradation throughout their ranges. Poorly regulated hunting for food and the pet trade, invasive species and collisions with man-made structures further threaten migratory songbirds at a number of stop-over or wintering sites, while climate change and habitat loss may be of increasing concern in the breeding ranges. A key conservation priority is to carry out intensive field surveys across the region while simultaneously tapping into citizen science datasets, to identify important stop-over and wintering sites, particularly for poorly-known or globally threatened species across South-East Asia and southern China for targeted conservation actions. Additionally, the advent of miniaturised tracking technology, molecular and isotopic techniques can provide novel insights into migration connectivity, paths and ecology for species in this migration system, complementing data from banding exercises and observation-based surveys, and could prove useful in informing conservation priorities. However, until most states along the East Asian-Australasian flyway ratify the Convention on the Conservation of Migratory Species of Wild Animals (CMS) and other cross-boundary treaties, the relative lack of crossboundary cooperation, coordination and information sharing in the region will continue to present a stumbling block for effective conservation of migratory passerines.

\section{Introduction}

Annually, an estimated four billion migratory birds (Newton 2007), the majority of which are passerines or songbirds, migrate from temperate Eurasia to lower latitudes in Africa and Asia during the boreal winter, with some 2.1 billion bound for Africa alone (Hahn et al. 2009). Traditionally, the African-European, and Nearctic-Neotropical migratory systems as well as the ecology of its 
constituent species have been relatively well studied given the long history of ornithology in Europe, Russia and North America, and have been the focus of multiple reviews (see Moreau 1972, Dolnik 1987, Rappole et al. 1983, Bolshakov 2001). Although detailed life history studies of some species in their breeding ranges in East Asia exist (e.g. Wang et al. 2006a, Imanishi et al. 2009, Gluschenko et al. 2011), the migration connectivity, strategies, wintering distributions and ecology of many long-distance passerine migrants in the East Asian migration system remain poorly understood (Greenberg and Marra 2005, Nam et al. 2011, Moores 2012). This is despite their ecological significance in both temperate and tropical biomes, given their abundance and roles in trophic (e.g. herbivory, predation) and transport processes (e.g. nutrient, parasites) (Bauer and Hoye 2014). Much of what is known about songbird migration ecology come from birdwatcher observations (e.g. Anon 2007, Round 2010, Emmanuel and Yordan 2013, Li et al. 2013), large-scale but localised bird banding studies (Komeda and Ueki 2002, Du et al. 2006, Kwon et al. 2007, Round et al. 2007, Gluschenko et al. 2010, Pronkevich 2011, Heim et al. 2012) and incidental observations on ships (Abe and Kurosawa 1982, Ellis et al. 1990, Choi 2004, Mizuta et al. 2009). Furthermore, the publication of much ornithological research in East Asia in vernacular languages (e.g. Russian, Chinese, Korean and Japanese), and in local journals has rendered much material inaccessible to western researchers.

From 1963 to 1973, the Migratory Animal Pathological Survey (MAPS) added considerable knowledge on the migration routes and survival of many species through its extensive ringing operations which banded over 1.2 million wild birds across India, East and South-East Asia (McClure 1974). However the project was conceived primarily to understand pathogenic transmission by migratory wild birds (McClure and Ratanawarabhan 1973, McClure 1974), and was later discontinued. Similarly, many later studies of migratory birds, particularly waterbirds were driven by interest in avian influenza surveillance (e.g. Valchuk and Huettmann 2006, Liu et al. 2011, Sivay et al. 2012). Subsequently, a combination of factors including technological and logistical limitations, charisma value and rapid wetland conversion across East Asia meant that much migratory bird research in the countries within the East Asian-Australasian Flyway is skewed towards largebodied waterbirds, ducks, waders, cranes (e.g. Higuchi 2012) and more recently, birds of prey. Conservation initiatives and collaborations in the region (e.g. Partnership for the East AsianAustralasian Flyway) are also designated primarily to conserve migratory waterbirds like Blackfaced Spoonbill Platalea minor (EAAFP 2012, Yu et al. 2013). By contrast, there is limited research on the migration patterns, connectivity and strategies of many songbirds, or their status in the wintering ranges (e.g. Black-throated Blue Robin Luscinia obscura as highlighted in Song et al. 2013). For instance, Wang et al. (2006b) noted only 1o publications on songbird migration in China between 1924 and 1989 , and none on stop-over ecology of songbird migrants. Moreover, the fact that many songbirds are too small for conventional tracking devices, mostly migrate nocturnally and often across open stretches of sea (Berthold 1993, Newton 2007, McKinnon et al. 2013) makes this even more challenging to study.

In recent years, the technology to study songbird migration has rapidly advanced and is now available as lightweight, light-level geo-locators, complemented by molecular techniques and stable isotope analysis, all which are increasingly being used in North America and Europe (e.g. Chabot et al. 2012, McKinnon et al. 2013), However, there are hitherto no published studies of passerine migrants in East Asia using these methods. Existing field-based studies of summer-breeding passerine migrants, at least in Japan (e.g. Yamamoto and Seto 1997, Higuchi and Morishita 1998, Kurosawa and Askins 2003, Namba et al. 2010) and Fennoscandia (Dale and Hansen 2013) underscored a lack of knowledge on how habitat loss and hunting in southern China and South-East Asia may have impacted wintering songbirds, many which are also affected by habitat loss and degradation in their breeding ranges (Kurosawa and Askins 2003). Others like Amano and Yamaura (2007) and Yamaura et al. (2009) have identified long-distance migration to the tropics as an ecological attribute linked to declining songbird species, at least in Japan. Some declines have also been identified for summer-breeding passerine migrants in Finland, especially species that winter in south China (e.g. Rustic Bunting Emberiza rustica) (Dale and Hansen 2013, Laaksonen and Lehikoinen 2013). 
In general, the paucity of long-term data collected over large spatial scales (see Moores 2012), particularly in South-East Asia, has prevented population trends and rates of decline of songbird migrants in the East Asian migratory system from being easily identified, as has been done in Europe (Sanderson et al. 2006, Vickery et al. 2014). However, increasing evidence of climate change impacts on African-European migrants (e.g. European Pied Flycatcher Ficedula hypoleuca) (Both et al. 2006), migration timing perturbations in some East Asian migrants (Harris et al. 2013), a continued loss and degradation of temperate (Kurosawa and Askins 2003) and taiga forests, especially in the Russian Far East (Kondrashov 2004) and north-east China (Chen et al. 2003), and rapid deforestation in tropical, non-breeding areas (Wang et al. 2006b, Sodhi et al. 2010), indicates that it is timely to re-evaluate the conservation status of migratory songbirds in the East Asian migration system.

Since the importance of the East Asian-Australasian Flyway for waterbirds and its associated conservation issues are well addressed in the existing literature (e.g. Higuchi et al. 2005, Crosby and Chan 2006, Cao et al. 2008a, Higuchi 2013), we aimed to summarise recent knowledge on migratory songbirds in this flyway, and highlight conservation issues for songbirds in this migratory system. First, we review the literature on published studies describing migratory songbirds, particularly that in local journals published in South Korea, Japan, China and the Russian Far East. Second, we describe avian diversity, distribution, wintering ecology and the conservation status of migratory songbirds that use the East Asian-Australasian Flyway, and compare this with the better known Western Palearctic-African (African-European) migration system which mirrors East Asia in many bird families and genera. Third, we identify and discuss key threats faced by migratory songbirds in the Flyway, particularly species wintering in tropical south China and SouthEast Asia. We conclude by highlighting research and conservation directions that can improve the conservation of songbird migrants in the East Asian migratory system.

\section{Methods}

\section{Definition of geographical scope}

Asia is the largest and most important continent for migratory birds globally in terms of total abundance and diversity. Much of the continent overlaps with the Palearctic, the world's largest biogeographic region, which is often subdivided into multiple subregions depending on the biota and geographical contexts used. Our review focuses on the East Asian-Australasian Flyway (Figure I), which overlaps with all of East and South-East Asia, north-eastern India (Arunachal Pradesh) and Bangladesh. In our review, we defined 'East Asia' as the Asian continent east of Transbaikalia in Russia ( $\left..105^{\circ} \mathrm{E}\right)$, south to the eastern margin of the Qinghai-Tibetan Plateau and eastern Himalaya, which encompasses Brazil's (2009) definition of 'East Asia'. The tropical regions of eastern Asia which are sometimes collectively defined as 'tropical East Asia' (Corlett 2009) extend from much of China south of the Yangtze River $\left(\mathrm{c} .30^{\circ} \mathrm{N}\right)$ to all of political SouthEast Asia west of New Guinea. While we did not consider north-eastern India and Bangladesh in this review, we acknowledged that many wintering songbirds there are shared with South-East Asia. In classifying bird species as long or short distance migrants, and identifying their wintering grounds, we used the distribution maps and descriptions provided in Brazil (2009) for eastern Russia, Japan, Korea and China; Coates and Bishop (1997) for Sulawesi, the Moluccas and Lesser Sundas; Coates and Peckover (2001) for New Guinea; Kennedy et al. (2000) for the Philippine Archipelago; Knystaustas (1993) for Russia; MacKinnon and Phillipps (1993) for Borneo, Sumatra and Java; MacKinnon and Phillipps (2000) for east-central China; Wells (2006) for the Thai-Malay Peninsula and Robson (2000) for mainland South-East Asia, corroborated by range information available on BirdLife International's online 'datazone' (BirdLife International 2013), the Xenocanto bird sound database (www.xeno-canto.org) and data reviewed in Irwin and Irwin (2005). We rechecked the distribution of all songbird species in our review based on our data as we have field experience with nearly all migratory songbird species in the flyway. 


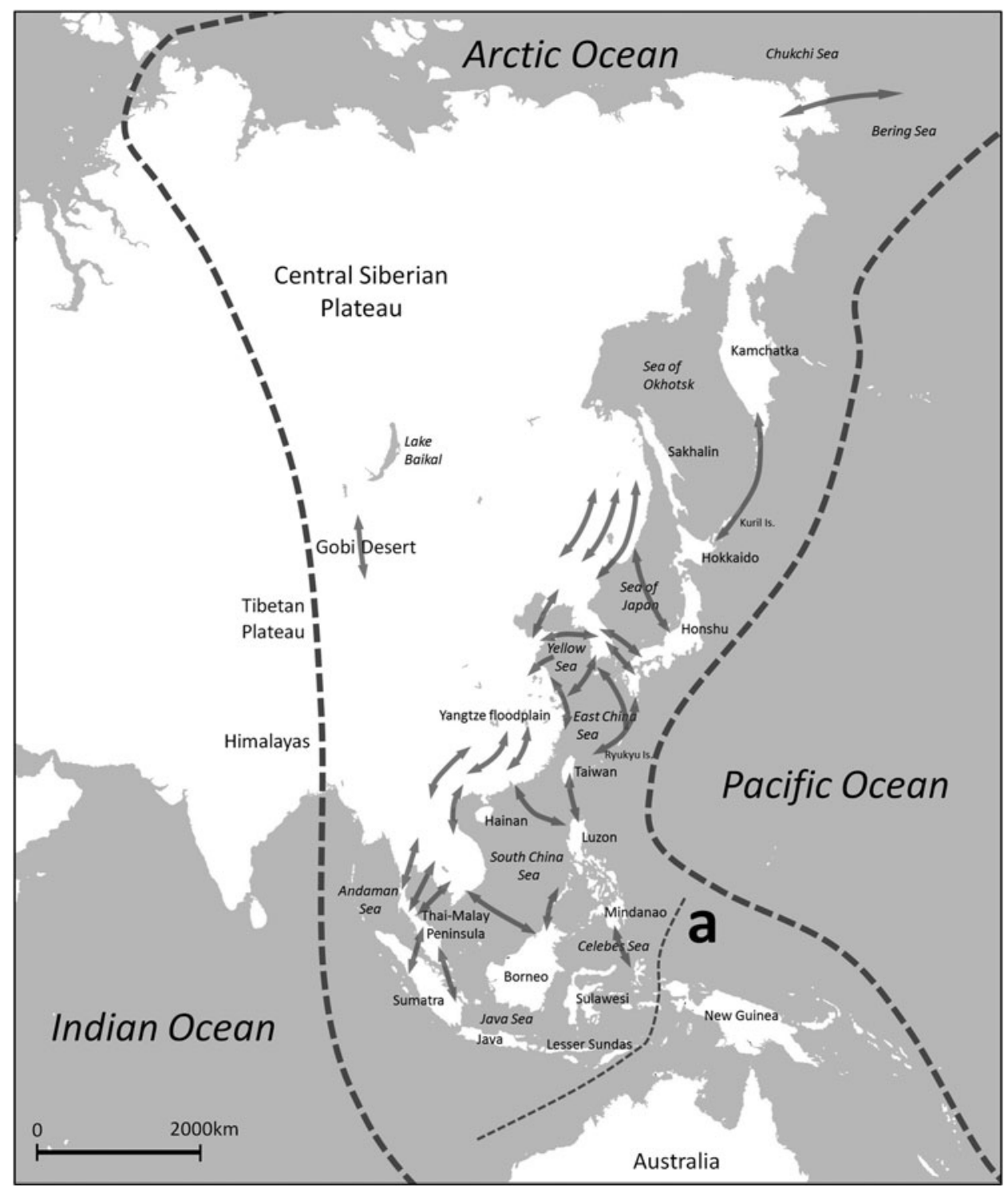

Figure 1. Map of the East Asian-Australasian Flyway showing approximate migration fronts for songbirds based on sites where large-scale migration movements have been observed. Dotted line ' $a$ ' denotes the south-eastern limit of the wintering ranges of most migratory songbirds ( $>95 \%$ ).

\section{Compilation of dataset}

We divided tropical East Asia, an important region for wintering songbirds, into six subregions of broadly similar climate and vegetation cover, namely: South China (south of the Yangtze River), mainland South-East Asia, Thai-Malay Peninsula, Greater Sundas, Philippines, and Wallacea. Mainland South-East Asia largely follows that as defined in Robson (2000) which includes collectively the territories of Myanmar, Thailand, Lao PDR, Cambodia and Vietnam, but excludes the Thai-Malay Peninsula which is biogeographically Sundaic. Wallacea follows the definition by 
Coates and Bishop (1997) and includes Sulawesi, the Lesser Sundas and the Moluccas. We omitted Australia, New Guinea and other Melanesian islands because most migratory songbirds there are either stragglers or vagrants (see Coates and Peckover 2001, Dingle 2004). Bird species are classified as regular migrants if there is published evidence to show that they occur seasonally in one region as breeders, and regularly (autumn-winter) in a region of lower latitude as non-breeders. For instance, Siberian Blue Robin Luscinia cyane is considered a regular wintering migrant in the Thai-Malay Peninsula and the Greater Sunda islands based on the literature (Wells 2006, Jeyarajasingham and Pearson 2012), range descriptions in available databases and our field experience, while the paucity of records of Yellow-breasted Bunting Emberiza aureola from the same region indicates that it is not a regular winter migrant. The species-level taxonomy and nomenclature used in our review is based on that in the BirdLife checklist v. 6.I (http://www.birdlife.org/ datazone/info/taxonomy), from which we also compiled information on species' breeding range size (in $\mathrm{km}^{2}$ ), overall population trends (stable, decreasing or increasing) and the presence of at least one migratory population in the review region. For family-level taxonomy, we chose to adopt that of the International Ornithologists' Union (Gill and Donsker 2013) to be in line with recent advances in avian phylogeny, but not expected to have significant influence on the conservation status of individual species. Given incomplete knowledge of the breeding ranges of many species in East Asia and errors in range estimates for some species (e.g. Arctic Warbler Phylloscopus borealis), we classified the breeding range data into size categories from 'tiny' to 'continental' to minimise the influence of these errors.

Since not all species of songbirds in the region are long-distance migrants, we only considered a songbird species a long-distance migrant if I) at least one, some or all populations are known to migrate to lower latitudes in temperate East Asia (e.g. Lapland Longspur Calcarius lapponicus), tropical South-East Asia (e.g. Common Stonechat Saxicola torquata) or a combination of both (e.g. White Wagtail Motacilla alba), and if 2) the species have at least one, some or all known populations breeding in Arctic East Asia (e.g. Asian Rosy-finch Leucosticte arctoa), temperate East Asia (Mugimaki Flycatcher Ficedula mugimaki) or mainland South-East Asia (Blue-winged Pitta Pitta moluccensis) (Tables $\mathrm{S}_{1}, \mathrm{~S}_{2}$ in the online Supplementary Material). Therefore, long-distance migrants in our review also include species termed as 'boreal' and 'intra-tropical' migrants in Kirby (2010). Species that are recognised as stragglers into our region of review but with significant, if not entire breeding populations outside (e.g. Largebilled Reed-warbler Acrocephalus orinus) are excluded, as are species with breeding populations that overwinter outside the region (e.g. Northern Wheatear Oenanthe oenanthe).

\section{Importance of East Asian-Australasian Flyway to migratory birds}

Boere and Stroud (2006) defined a 'flyway' as the entire geographical range of a species, or aggregations of related species within which populations migrate from breeding to non-breeding areas. Although the flyway approach provides a useful generalisation for most (but not necessarily all) species that migrate within it, Kirby (2010) acknowledged the usefulness of the 'flyway' concept in organising conservation actions between multiple countries. Using flyway definitions commonly used for waterbirds (Boere and Stroud 2006, Kirby 2010), up to five flyways overlap with Asia. The East Asian-Australasian Flyway (Figure 1) encompasses all of East Asia, South-East Asia, north-east India, Australia, the west Pacific islands and parts of Alaska (see Alerstam et al. 2008) and overlaps with the territories of 22 countries (EAFFP 2012). This migration system is recognised as the most species-rich flyway globally, hosting approximately 477 species of landbirds and a further 201 waterbirds (Kirby et al. 2008), with increasing diversity and proportion of migrating species as latitude increases from its equatorial regions to northern Siberia (Kuo et al. 2013). The East Asian-Australasian Flyway is especially important for waterbirds, of which more species, and species of conservation concern occur here than any other migration system (Crosby and Chan 2006). Not surprisingly, much of the research (e.g. Cao et al. 2008b, Amano et al. 2010) and many conservation directions for the East Asian-Australasian Flyway to date (EAAFP 2012) 
have focused on shorebirds, cranes (e.g. Shiu et al. 2006), birds of prey (e.g. Germi et al. 2009, Higuchi 2013) and waterfowl, partly also due to interest in migratory bird transmission of avian influenza (e.g. Zhao 2006, Cheng et al. 2010, Sivay et al. 2012). Despite this, it is still widely recognised as one of the world's most poorly understood flyways (Newton 2007).

Our review identified at least 254 species of songbirds that undertake latitudinal migration in the East Asian-Australasian Flyway (Table $\mathrm{S}_{1}$ ). The majority (I70 species, 67\%) are long-distance migrants of which about 155 species have breeding populations in temperate/Arctic East Asia. At least 83 additional species are short-distance migrants, many also altitudinal migrants that descend from the Tibetan Plateau, eastern Himalaya and the region's uplands to nearby lowlands of central, east and south China, north-east India and mainland South-East Asia during winter. Given ongoing taxonomic revisions based on modern phylogenetic tools, it is certain that the total diversity of migratory songbirds recognised for this Flyway will increase, with some taxa having smaller distributions than before, when consensus on certain species complexes (e.g. Alström et al. 2011, Lobkov 2011, Leader and Carey 2012) is achieved.

The 170 species of long-distance songbird migrants identified include: 1 ) species that breed in Arctic Russia and western Alaska and overwinter in temperate East Asia; 2 ) species that breed in temperate East Asia and subarctic Russia that winter in the Asian tropics and/or the lower latitudes of East Asia; or, 3) species that are 'intra-tropical migrants' that breed within the subtropics and winter at equatorial latitudes. Temperate East Asia, which includes eastern Russia from Transbaikalia to Yakutia, Chukotka and the Russian Far East, eastern Mongolia, northern China, the Korean Peninsula and the Japanese archipelago, supports about 55 wintering species, and is especially important for granivorous migrants such as buntings and finches. In the East Asian tropics, diversity of wintering songbirds is highest in southern China and mainland South-East Asia (Table 2, Figure 2), and decreases eastwards to the Philippine Archipelago and Wallacea. Collectively, Sulawesi, the Moluccas and Lesser Sundas support only 16 regular songbird migrants and no species reach continental Australia as regular winterers (Dingle 2004). New Guinea supports only about five wintering Palearctic

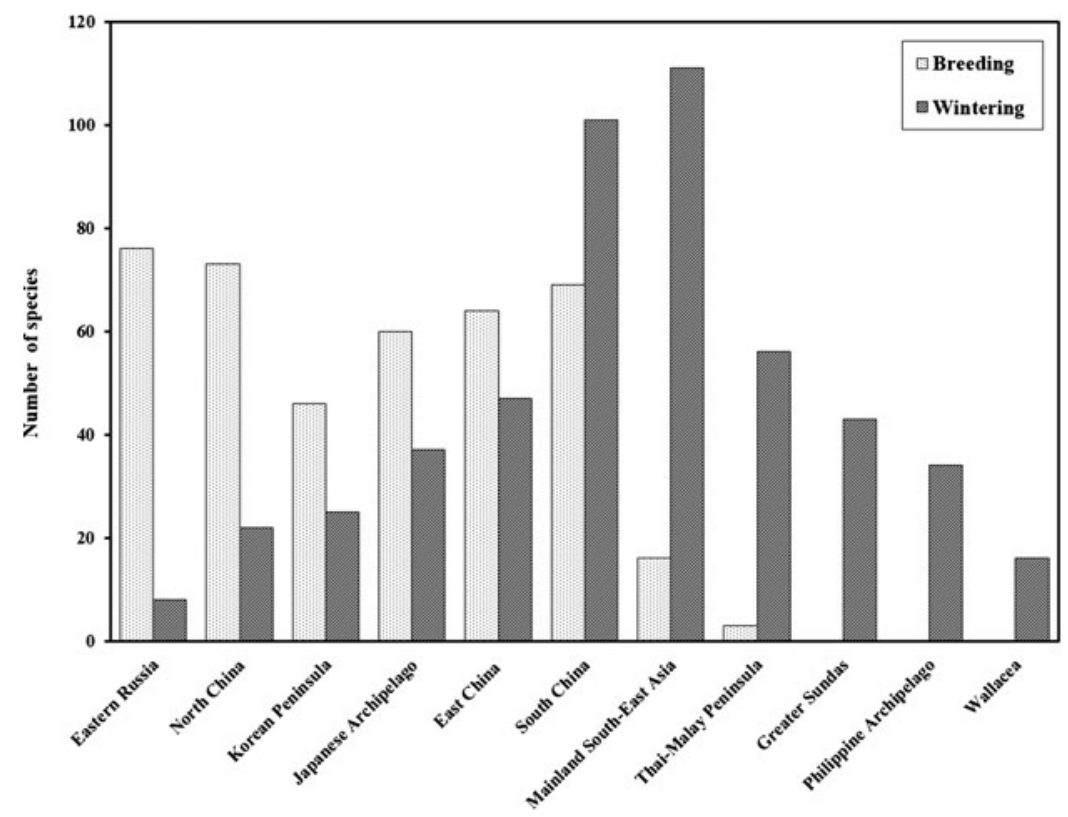

Figure 2. Bar chart showing distribution of breeding and wintering songbird species richness across temperate East Asia and tropical East Asia (South-East Asia and South China), classified by geographic region as per our definitions. 
songbirds. Similarly, few other non-passerine landbird migrants (i.e. cuckoos) reach New Guinea or Australia as regular wintering species (Dingle 2004). Consequently, the East Asian-Australasian Flyway is probably more appropriately termed as the 'East Asian' flyway, at least in the context of songbirds.

\section{Taxonomic diversity of songbirds in the East-Asian Flyway}

Most landbird migrants in the East Asian migration system are songbirds, with at least 254 species from 32 families (Table 1 ; Table $\mathrm{S}_{1}$ ), of which at least one population undertakes seasonal latitudinal migration. Of 170 long-distance migrants, 129 species have populations that overwinter in the tropics, with the greatest diversity of wintering songbirds in mainland South-East Asia (III species) and southern China (IOI species) (Table 2, Figure 2). This is a much higher total than West and East Africa (see Morel and Morel 1992, Pearson and Lack 1992), which when collectively considered, only support 83 species from 14 families in a larger area.

The two East Asian families with the greatest diversity of migrants are the insectivorous Muscicapidae (flycatchers and chats) and Phylloscopidae (leaf warblers), of which the majority of constituent species are long-distance, tropical migrants. Both families are also well represented in tropical Africa as migrants (Figure $\mathrm{S}_{1}$ ), which supports at least 23 Muscicapidae species although only four species of leaf-warblers winter there. Additionally, Emberizidae (buntings) and Fringillidae (finches) are well-represented in the East Asian Flyway but the majority of species winter in temperate East Asia. For example, 14 of 22 buntings overwinter in temperate Asia while no species winter in the Thai-Malay Peninsula or the Greater Sundas. Similarly, finches are well-represented in temperate East Asia with at least 16 wintering species. These geographical patterns of winter distribution across migratory songbirds of different dietary guilds are likely to be tied to spatio-temporal variation of food resources in winter. In particular, distributions of ectothermic arthropods are strongly influenced by temperature and these are thus more abundant in warmer areas (Shiu and Lee 2003) at lower elevations and latitudes. Insectivores like leaf-warblers migrate further south into the tropical belt where insect abundances are higher (Newton 2007), while granivores such as buntings and finches can still forage for seeds in coniferous forests and woodland in temperate Asia during winter.

Table 1. Major taxonomic groups with migratory representatives within the East Asian-Australasian Flyway (migratory stragglers and vagrants are excluded).

\begin{tabular}{lrr}
\hline Taxonomic group & Number of migratory species & $\begin{array}{c}\text { Species with long-distance } \\
\text { migratory populations }\end{array}$ \\
\hline Ducks and geese & 44 & 42 \\
Divers & 4 & 4 \\
Waders & 60 & 58 \\
Cranes and buttonquail & 7 & 7 \\
Rails and bustards & 12 & 12 \\
Storks, spoonbills and pelican & 6 & 6 \\
Cormorants & 4 & 1 \\
Herons and bitterns & 17 & 17 \\
Grebes & 5 & 5 \\
Hawks and falcons & 32 & 30 \\
Gulls and terns & 23 & 23 \\
Cuckoos & 11 & 10 \\
Owls & 4 & 4 \\
Kingfishers, bee-eaters, rollers & 7 & 7 \\
Songbirds & 254 & 170 \\
Total species & 490 & 396 \\
\hline
\end{tabular}


Table 2. Breakdown of long-distance migratory songbirds by wintering geographical regions across temperate and tropical East Asia (South-East Asia and South China).

\begin{tabular}{lcccc}
\hline Geographical region & $\begin{array}{l}\text { Number of wintering } \\
\text { species (\% of total pool) }\end{array}$ & $\begin{array}{l}\text { Threatened/ } \\
\text { near-threatened }\end{array}$ & $\begin{array}{l}\text { Declining trends } \\
\text { recognised by BirdLife }\end{array}$ & $\begin{array}{l}\text { Species limited } \\
\text { as winterer to } \\
\text { region }\end{array}$ \\
\hline Temperate East Asia & 55 & & & \\
East Siberia & $8(14 \cdot 5)$ & 0 & 5 & 0 \\
North China & $22(40.0)$ & 1 & 14 & 0 \\
Korean Peninsula & $25(45 \cdot 5)$ & 1 & 12 & 0 \\
Japanese Archipelago & $37(67 \cdot 3)$ & 3 & 19 & 1 \\
East China & $47(85 \cdot 5)$ & 4 & 17 & 0 \\
Tropical East Asia & 129 & & 28 & 2 \\
South China & $101(78.3)$ & 6 & 14 & 3 \\
Philippine Archipelago & $34(26.4)$ & 4 & 26 & 9 \\
Mainland South-East Asia & $111(86.0)$ & 8 & 16 & 1 \\
Thai-Malay Peninsula & $56(43.4)$ & 3 & 16 & 1 \\
Greater Sundas & $43(33 \cdot 3)$ & 3 & 4 & 0 \\
Wallacea & $16(12.4)$ & 0 & 56 & - \\
Total & 170 & 21 & & \\
\hline
\end{tabular}

\section{Songbird migration across the East Asian Flyway}

Long-distance migrants which form the majority of migratory songbirds include species with at least one population (incomplete migrant), or all populations (complete migrant) that travel from temperate breeding grounds to tropical wintering grounds, or within temperate areas but at lower latitudes prior to the boreal winter. Populations of a few species of long-distance migrants (e.g. Lapland Longspur, Asian Rosy-finch) fly from breeding grounds above the Arctic Circle to overwinter in relatively warmer, temperate areas in East Asia (e.g. eastern China, Japan) (see Brazil 2009). Furthermore, some species with distributions that straddle temperate and tropical regions may have non-migratory and migratory populations (e.g. Asian Paradise-flycatcher Terpsiphone paradisi), resulting in leapfrog migration patterns.

A minority of the migratory songbirds in the Eastern Palearctic are recognised as short-distance migrants, especially species occurring at subtropical latitudes, high elevations and some granivorous temperate species (e.g. finches). Many species that breed in the high-elevation forests of the eastern Himalaya, Qinghai-Tibetan Plateau, central China or northern South-East Asia are short-distance and/or altitudinal migrants that descend to overwinter in the lowlands and riverine plains of South-East Asia, especially along the upper Ayeyarwaddy (see Tordoff et al. 2007) and north-east India, the Himalayan foothills and other habitats at lower elevations in mainland South-East Asia and south China (Luo et al. 2014). These short-distance migrants include many chats, finches, thrushes and flycatchers.

In general, the migration paths taken by these songbirds are diverse, but are undertaken during both day and night and on broad fronts (Bruderer 1997, Chernetsov 2012, Moores 2012), sometimes involving large water crossings, especially for species breeding in the Alaskan Taiga, Sakhalin Island, Japan, Taiwan and islands in the Yellow Sea (e.g. Mizuta et al. 2009), species wintering in the islands of South-East Asia (e.g. Gibson-Hill 1950, Simpson 1983a, Ellis et al. 1990), or flight across mountainous regions (e.g. Du et al. 2006, Han et al. 2007). Moreover, migratory landbirds may be concentrated in bottlenecks of land and islands if sea crossings are involved. This is corroborated by observations of large concentrations of landbird migrants on particular small Yellow Sea islands like Socheong-do, Eocheong-do, Hong-do and Heuksan-do in Korea, as well as Hegurajima and the Ryukyu Islands in Japan (Kuroda 1971, Kim and Yoo 2010, Nam et al. 2011, Moores 2012) and in South-East Asia (e.g. Chasen 1932, McClure 1974). 
In South China in Yunnan, Jiangxi and Hunan provinces (Tang et al. 2003, Xiao et al. 2005, Han et al. 2007), and on the Thai-Malay Peninsula (Chasen 1932, McClure 1974), extensive nocturnal trapping exercises have also revealed details of the migratory dynamics of night-flying songbirds as they cross mountainous barriers, particularly the influences of weather conditions on migration (Yang et al. 2009).

\section{Breeding and wintering ranges of migratory songbirds}

Unlike songbirds breeding in temperate Europe and North Africa, many which have relatively large ranges extending into Central Asia and the Middle East (e.g. Common Nightingale Luscinia megarhynchos), East Asian migratory songbirds have generally smaller ranges. We found that breeding range sizes of long-distance migrants wintering in South-East Asia differed significantly from European species wintering in the Afrotropics $(Z=-3.9432$, Mann-Whitney $U=4762.5$, $P<$ o.001) (Figure 3). Twenty-five species of summer breeding songbirds in East Asia have small breeding ranges of less than $250,000 \mathrm{~km}^{2}$, (Figures 3 and 4) compared to only five such species wintering in the Afrotropics. The insular geography of temperate East Asia, especially Sakhalin Island, the Japanese archipelago and a number of small island groups in the Yellow, East China Seas and the Sea of Japan (also known as the East Sea) has contributed to the evolution of a number of breeding endemics with relatively small ranges (Moores 2012), including Japanese Robin Luscinia akahige, Pleske's Grasshopper-warbler Locustella pleskei and Sakhalin Leafwarbler Phylloscopus borealoides. Among these, some species have entire breeding ranges confined to a few small islands, notably Izu Leaf-warbler P. ijimae (Brazil 2009). Their relatively small populations indicate that these narrow-ranged species are likely to be more sensitive to threats at stop-over or wintering sites.

There are few published data on the wintering distribution of many migratory songbirds in the flyway and the entire wintering range of some species was unknown until recently

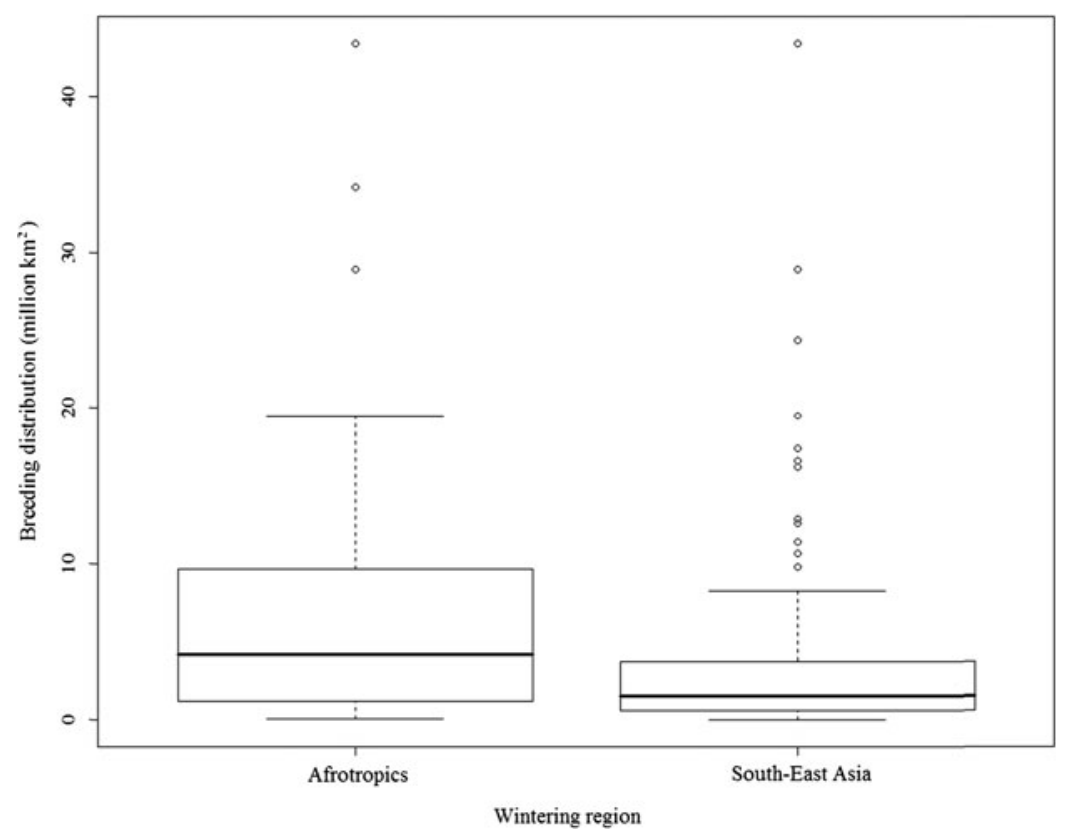

Figure 3. Boxplot comparing estimated breeding range size of long-distance, migratory songbirds in the Afrotropics $(n=83)$ and South-East Asia $(n=129)$. 


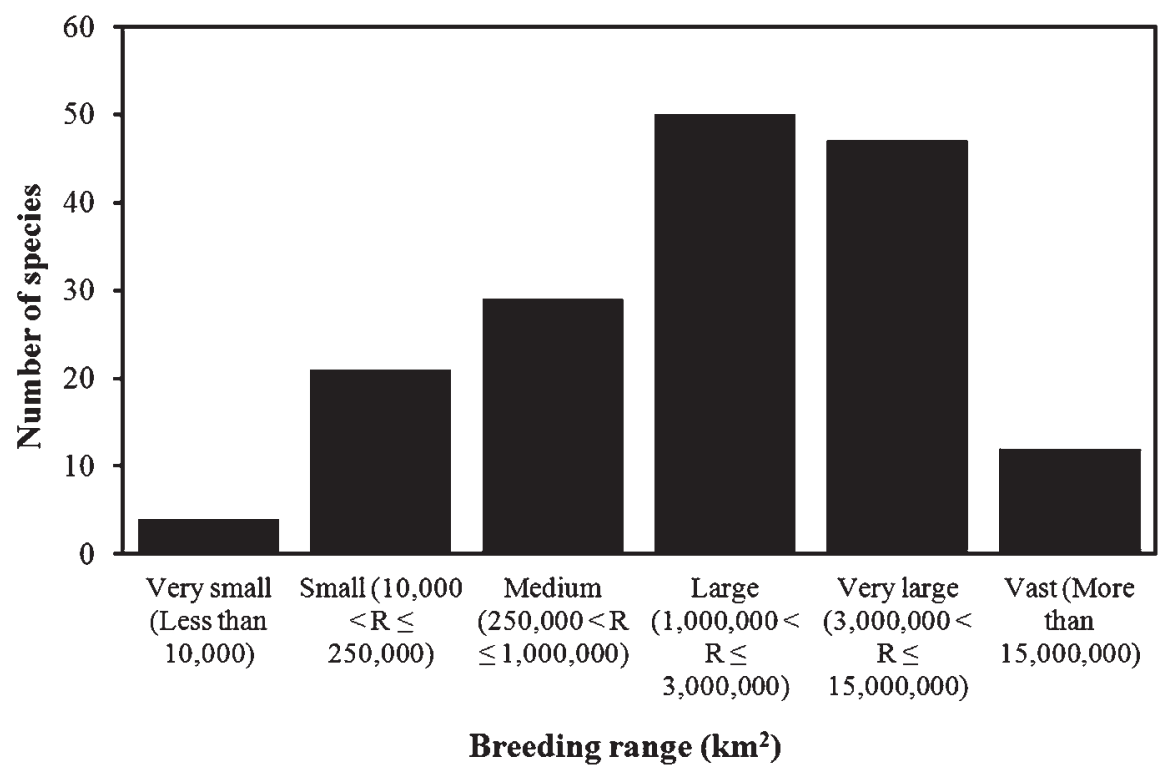

Figure 4. Bar chart showing distribution of breeding range size classes for songbird species with range size estimates provided in the BirdLife 'Datazone' (BirdLife International 2013).

(e.g. Sakhalin Leaf-warbler) (Yap et al. 2014). However, the insular geography of much of South-East Asia implies that many species have naturally disjointed wintering populations spread across multiple landmasses, while a few have most, if not the entire wintering populations concentrated onto one island. For instance, the abundant Siberian Blue Robin is known to winter across mainland South-East Asia, the Thai-Malay Peninsula, Sumatra, Borneo (Robson 2000, Wells 2006), including even small islands in the Riau Archipelago off Sumatra (D. L. Yong unpubl. data). Conversely, the entire population of the Fairy Pitta Pitta nympha is thought to winter only in Borneo (BirdLife International 2013).

There are also migratory songbirds that winter exclusively along the East Asian flyway, but draw from populations widely distributed across temperate Eurasia. The best example is the widespread Arctic Warbler P. borealis, which breeds across the Russian taiga to Fennoscandia (Laaksonen and Lehikoinen 2013), and across the Bering Sea into Alaska (Alerstam et al. 2006). The global population of this species is concentrated mostly in southern China, mainland South-East Asia, the Thai-Malay Peninsula, Philippines and the Greater Sundas in winter (BirdLife International 2013), and wintering Arctic Warblers can occupy diverse habitats from urban greenery to mangroves, evergreen forests and montane elevations (Robson 2000), and at relatively high densities (McClure 1967, Yong et al. 2013). While the migration routes, wintering ecology and distribution of each taxonomic unit remains poorly known, its abundance and high detectability indicates that the Arctic Warbler may be a suitable model species for studying long-distance passerine migration between temperate Eurasia and the East Asian tropics.

\section{Migrating songbirds at stop-over sites on the East Asian Flyway}

\section{East Asia}

East Asia's habitats provides an important 'connecting region' in the form of staging or stop-over sites for migrating songbirds moving between the temperate breeding and tropical wintering grounds for 
resting and refuelling, which are critical to the life history and survival of these migrants (Bairlein 1985, Ma et al. 2005). Although stop-over ecology has been less studied here than in Europe (see Chernetsov 2012), there is a growing number of studies, in addition to a relatively long history of regular bird banding exercises to document bird migration, especially in Japan (e.g. Yoshii et al. 1989, Komeda and Ueki 2002, Ozaki 2008), South Korea (e.g. Won et al. 1966) and China where a 30-year old national bird banding programme exists (Wang et al. 2006b). Similar bird banding programmes also exist in the Russian Far East (e.g. Valchuk et al. 2005, Pronkevich et al. 2007, Heim et al. 2012). Socheong-do, Oeyeon-do, Eocheong-do, Heuksan-do and Hong-do islands in the Yellow Sea are particularly well-studied by South Korea-based researchers and much has been learnt on diverse aspects of seasonal migratory patterns (Park et al. 2008, Kim 2009, Won et al. 2010, Moores 2012, Choi et al. 2013); stop-over mortality (Bing et al. 2012), and migration strategy (Nam et al. 2011). In Japan, species-specific studies such as Nakamura and Ishizawa (1965) have documented migratory timings and speed for Gray's Grasshopper-warbler Locustella fasciolata through Honshu, as well as migration flocking behaviour. These studies also revealed that migrants suffered high mortality rates during stop-over, which arose from man-made causes including window strikes and predation by feral cats Felis catus (Bing et al. 2012), migrating raptors (Ellis et al. 1990) and other migrating songbirds (Hong et al. 2010).

There are fewer stop-over ecology studies in mainland China or Taiwan, but those that exist are useful in understanding the migration ecology of some of the more abundant songbirds in the flyway. In Taiwan, Severinghaus (1996) sampled Brown Shrikes Lanius cristatus, an abundant passage and wintering species at suburban sites, and showed that the species experienced heavy competition for hunting territories, resulting in territorial compression. According to this study, $24 \%$ of transient Brown Shrikes passed before wintering birds arrived, thus avoiding competition, while territorial behaviour was very evident between birds present. In northern China, Wang et al. (2006b) sampled Orange-flanked Bush-robin Tarsiger cyanurus at a stop-over site in Heilongjiang and was able to document gains in mass by birds on passage, as well as evidence of differential arrival timings of males and females, a pattern that might indicate temporal partitioning to reduce competition. Age or sex-related temporal partitioning within species as shown in Wang et al. (2006b) in China and in Nam et al. (2011) in Korea, or between ecologically similar species can minimise competition during stop-over, but may also result from differential latitudes of the breeding ranges, as suggested in Imanishi et al. (2009) which studied autumn migration timings of three Phylloscopus warblers in Japan.

In the Russian Far East, the increasing numbers of surveys and bird ringing exercises are beginning to reveal the pathways, abundance, diversity and stop-over ecology of songbird migrants that pass through study sites there, especially in the Lower Amur region in Primorsky, Khabarovsk and Amur oblasts (e.g. Valchuk and Huettmann 2006, Gluschenko et al. 2010, Pronkevich et al. 2007, Pronkevich 2011, Heim et al. 2012). Bird ringing work at the wellstudied Muraviovka Park, for instance, has established it as a site of importance to songbirds on migration across the Amur region in autumn. Data from bird ringing at Muraviovka Park has allowed stop-over timings for various species to be established and may be as short as one day for the Yellow-throated Bunting Emberiza elegans to more than two weeks for species like the Pallas's Bunting E. pallasi (Heim et al. 2012). Other studies like Valchuk et al. (2005) have established multiple migration routes of the Rustic Bunting connecting stop-over sites in the Russian Far East and parts of Japan.

\section{South-East Asia}

Migratory songbird ecology in passage or stop-over habitats (Ruth et al. 2012), and South-East Asia in particular remains poorly known (e.g. Mahood et al. 2013b). Ever since the extensive banding studies in the 1960s (e.g. McClure 1974) and the bird surveys in the Straits of Malacca's islands (e.g. Gibson-Hill 1950), there are few recent studies examining aspects of stop-over ecology of migratory songbirds in the East Asian tropics. Anecdotal observations and studies based on 
birdwatching data suggest that some species exhibited differential passage peaks during migration (e.g. Round 2010), used a relatively large breadth of habitats during stop-over, including poor quality or small habitat patches on islands and in built-up areas (e.g. Anon 2007, Yong and Liu in press) and may suffer high mortality due to predation by migrating hawks (e.g. Ellis et al. 1990). In Thailand, Round (2010) analysed long-term birdwatching records of three migratory songbirds (Tiger Shrike Lanius tigrinus, Mugimaki Ficedula mugimaki and Yellow-rumped Flycatcher F. zanthopygia) on passage and found differential passage timing peaks for the three species, as well as differential arrival timings of males and females, suggesting protandrous migration patterns. Mahood et al. (2013 b) reviewed passage records of songbirds in northern Vietnam and documented many species stopping over in apparently poor-quality urban habitats, especially in Hanoi city. Yong and Liu (in press) examined temporal variation of records of Brown-chested Jungleflycatcher Rhinomyias brunneatus at stop-over sites in Singapore in October-November and reported relatively high densities of the species across a habitat gradient from poor (secondary scrub) to good quality primary forest habitat, suggesting that stop-over habitat quality may have less impact on transient birds.

\section{Use of wintering habitats by migratory songbirds}

\section{Overview}

Almost all terrestrial habitats across East and South-East Asia are used by wintering songbirds to some extent (Figure 5). Habitat use varies with species, with generalists like the Arctic Warbler occurring across a gradient of habitats, while species with narrower niches (e.g. forest and wetland specialists) occur in limited habitat types (Johnson et al. 2006). Regular assemblages of migratory songbirds that form in wintering sites can attain relatively high densities and species richness (e.g. Karr 1976), with as many as 15 species in some lowland rainforests in the Thai-Malay Peninsula. What remains unclear is how wintering songbird communities exploit or partition resources or interact with other species, as well as the demographic patterns within the wintering populations (e.g. Ornat and Greenberg 1990).

\section{Agricultural land and urban areas}

Cultivated land, which currently covers $48.2 \%$ of the land area across East Asia (The World Bank database, accessible at http://data.worldbank.org) is important to many species of wintering songbirds that otherwise depend on open country or scrub habitat, particularly some Phylloscopus and Locustella warblers, buntings, redstarts, shrikes and wagtails (e.g. Moores 2013), and may be increasingly so if other wintering habitats such as forests are cleared (Johnson et al. 2006). However, farming intensity, farming methods, season and crop types (e.g. Dänhardt et al. 2010) are all likely to influence the composition of wintering songbirds therein, given species-specific habitat preferences and habitat breadths. Many shrikes, larks, wagtails, pipits and buntings have broader habitat preferences and may occur across a mosaic of agricultural landscapes while some species are dependent on finer-scale habitat features like presence of water bodies, shade or extent of shrub cover. Some Locustella warblers and buntings, for example, are associated with wetter habitats like flooded grassland and can utilise cultivated land like paddyfields (e.g. Fujioka et al. 2010).

Paddyfields, which are among the most often sampled agricultural landscapes for wintering migrant birds in East Asia support six songbirds in Japan and Korea during winter, and a number of breeding migrants in summer (Fujioka et al. 2010, Stafford et al. 2010). In subtropical Hong Kong, studies using birdwatching data and regular surveys, like Carey et al. (2001) suggested that remnant paddyfields are important for wintering buntings and Common Stonechat Saxicola torquatus. On the other hand, Azman et al. (2011) found few migratory songbirds in paddy fields in Peninsular Malaysia, including the Barn Swallow Hirundo rustica and Brown Shrike. 

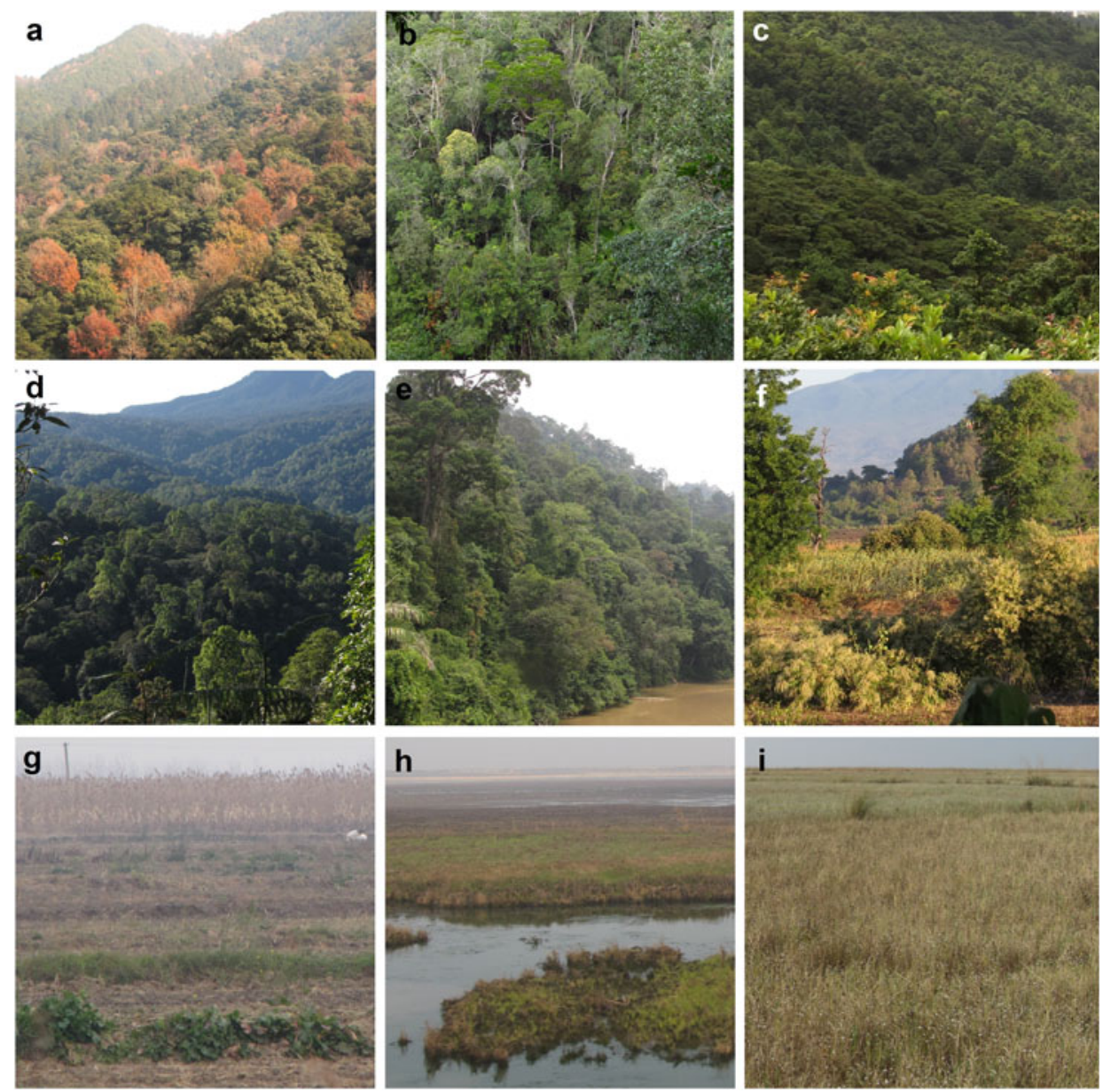

Figure 5. Major wintering habitats for songbird migrants across East and South-East Asia: a) Mixed deciduous forest, Jiangxi, south-east China, b) Broadleaved evergreen forest, Hainan, south China, c) Mixed woodland, Hong Kong, south China, d) Submontane rainforest, west Sumatra, Indonesia, e) Lowland rainforest, Pahang, Peninsular Malaysia, f) Agricultural areas abutting dry deciduous woodland, Bagan, Myanmar, g) Agricultural fields, Jiangsu, east China, h) Freshwater wetlands, Poyang Lake, south-east China, i) Semi-inundated grassland, Tonle Sap, Cambodia (All photos: Ding Li Yong).

Oil palm plantations which increasingly cover much of Sundaic South-East Asia (Fitzherbert et al. 2008) support few migratory songbirds, and lack species dependent on forests like Siberian Blue Robins, as shown by Azman et al. (2011). Similarly, urban areas are also generally poor in wintering migrant bird diversity and abundance. Zhou et al. (2012) sampled bird diversities in Hong Kong and found few species of wintering songbirds in urban parks, and those that occurred were at lower densities than in secondary forests. No migrant species for example were among the top 1o most abundant species in urban parks, but Lemon-rumped Warbler Phylloscopus proregulus, Inornate Warbler P. inornatus and Grey-backed Thrush T. hortulorum were among the most abundant birds in secondary forests in winter (Zhou et al. 2012). In urban areas in Singapore and Peninsular Malaysia, only two species regularly utilise urban parkland (Yong et al. 2013), notably Arctic Warbler and Asian Brown Flycatcher Muscicapa dauurica. 
Table 3. Wintering habitat usage by long-distance migratory songbirds in three key habitat types in major landmasses across insular South-East Asia.

\begin{tabular}{lcrlllll}
\hline Species richness/ $(\%)$ & $\begin{array}{l}\text { Thai-Malay } \\
\text { Peninsula }\end{array}$ & Sumatra & Borneo & Java & Luzon & Mindanao & Sulawesi \\
\hline Lowland forest & $27(50.9)$ & $16(45.7)$ & $14(40.0)$ & $13(52.0)$ & $10(33.3)$ & $6(33.3)$ & $3(20.0)$ \\
Montane forest & $14(26.4)$ & $11(31.4)$ & $8(22.9)$ & $9(36.0)$ & $8(26.7)$ & $5(27.8)$ & $3(20.0)$ \\
Wetland & $6(11.3)$ & $4(11.4)$ & $5(14.3)$ & $3(12.0)$ & $5(16.7)$ & $3(16.7)$ & $2(13.3)$ \\
Habitat generalist & $19(35.8)$ & $11(31.4)$ & $12(34.3)$ & $7(28.0)$ & $11(36.7)$ & $8(44.4)$ & $8(53 \cdot 3)$ \\
Total & 53 & 35 & 35 & 25 & 30 & 18 & 16 \\
\hline
\end{tabular}

\section{Natural wetlands}

Natural wetlands, which include riparian forests, seasonally-flooded grasslands, freshwater marshes and coastal (salt) marshes are important wintering habitats for many long-distance migrants like swallows, buntings, reed- and grasshopper-warblers, Luscinia and Saxicola chats, and Chinese Penduline-tit Remiz consobrinus (Nisbet and Medway 1974, Carey et al. 2001, Gan et al. 2010). Even newly formed coastal wetlands can attract wintering buntings, warblers and robins, as shown by surveys of wetland on shoals in the Yangtze estuary (Ma et al. 2007). Many species of robins, redstarts, shortwings and flycatchers that breed at high elevations in the Eastern Himalaya and mountain ranges of south-central China (e.g. Qinling and Sichuan mountains) also descend to the riparian wetlands of northern Myanmar, Thailand and north-east India in winter (see Rasmussen and Anderton 2005, Tordoff et al. 2007, Song et al. 2013), including two poorly known chats (i.e. Firethroat Luscinia pectardens and Black-throated Blue Robin L. obscura).

Much knowledge on the usage and distribution of wintering songbirds in wetlands are based on birdwatching data, field surveys, past (e.g. Nisbet and Medway 1974, McClure 1974) and ongoing banding exercises (e.g. Round and Rumsey 2003, Round and Fisher 2009). McClure (1974) for example, banded hundreds of thousands of swallows and other wintering songbirds, including many reed-warblers in reed beds fringing the Bung Boraphet Lake in central Thailand during the MAPS project. Recent surveys in riparian habitats and wetlands along the tributaries of the upper Ayeyarwaddy, northern Myanmar by Tordoff et al. (2007) also documented a number of migratory songbirds wintering there, including short-distance and altitudinal migrants like the Rusty-bellied Shortwing Brachypteryx hyperythra. Increasingly polluted, overfished, converted for agriculture or threatened by hydrological impacts of damming (Dudgeon 2000), some of the most important examples of large natural wetlands for wintering songbirds in the region include Chiang Saen and Bung Boraphet lakes in Thailand, wetlands fringing the Tonle Sap lake in Cambodia, riparian grassland and oxbow lakes along the upper Chindwin in Myanmar, the Dongting and Poyang lake systems of the Lower Yangtze floodplain, and coastal marshes on the Yangtze Estuary and Jiangsu-Zhejiang coast in China.

\section{Forests}

Broadleaved evergreen and mixed forests are of major importance as wintering habitats for migratory songbirds across south China and South-East Asia, and significantly more so compared to the Afrotropics (Figure 6) (e.g. Karr 1976). Compared to tropical Asia, many authors acknowledge that wintering songbirds in Africa are less forest-dependent (e.g. Moreau 1972, Morel and Morel 1992, Pearson and Lack 1992) despite the large extent of rainforest blocks in West, Central and East Africa (Malhi et al. 2013).

We identified over 50 migratory songbird species in South-East Asia that are dependent on broadleaved evergreen forests as wintering habitat, a proportion significantly higher than in the Afrotropics $\left(\chi^{2}=14.629, \mathrm{df}=1, P<0.001\right)$. Lowland rainforests in the Thai-Malay Peninsula, 
for example can support species-rich assemblages of as many as 27 species of wintering warblers, flycatchers and thrushes (Table 3), with migrants forming 6-15\% of total bird abundance (Karr 1976). Even higher wintering songbird diversities can be expected in Indochinese evergreen forests in the lowlands and at submontane elevations. The well-studied submontane Mo Singto plot (c.3o ha) at Khao Yai National Park, Thailand for example, supports about 29 species of wintering long-distance migrants and a smaller number of short-distance/altitudinal migrants (Round et al. 2011). Much of this wintering songbird diversity can be attributed to wintering Phylloscopus warblers (about nine species) and which also made up as much as $14 \%$ of bird abundances (Round et al. 2011).

In general, the proportion of wintering songbird diversity in forests is high, with up to $52.0 \%$ and $20.0 \%$ (Table 3 ) of migratory songbirds across insular South-East Asia utilising lowland evergreen forests as wintering habitats. Diversity and species richness of wintering assemblages decrease with elevation (Table 3), also demonstrated by surveys of forest migrant bird assemblages across elevation gradients in Taiwan (e.g. Shiu and Lee 2003). Moreover, there also appears to be variation in habitat preference for some species across the wintering range. For example, the Narcissus Flycatcher Ficedula narcissina winters in hilly to mid-elevation montane forest in Borneo but the subspecies F. n. elisae which winters in the Thai-Malay Peninsula, is dependent on lowland rainforest (Wells 2006). Besides some broad patterns highlighted here, we acknowledged that there is still a dearth of knowledge on the composition, community structure, population dynamics and turnover of wintering songbird assemblages across various forest types (e.g. coniferous, broadleaved evergreen, dry dipterocarp, mangroves) and across gradients of disturbance and degradation in the South-East Asian tropics.

\section{Discussion}

\section{Conservation status of migratory songbirds in the East Asian Flyway}

Of 254 species of migratory songbirds reviewed, 15 are presently listed by BirdLife International (2013) as threatened, the majority long-distance migrants ( $1_{3}$ species) (Tables $\mathrm{S}_{2}, \mathrm{~S}_{5}$ ) and the highest for any migration system. Seven species are 'Near Threatened', mostly short-distance migrants. The higher proportion of threatened long-distance migrants appears consistent with reviews of other migration systems (e.g. Vickery et al. 2014). Additionally, 56 long-distance migratory songbirds are reported to show declining trends (Table 2; Table $\mathrm{S}_{3}$ ) although the actual figure may be even higher. One species, the 'Critically Endangered' White-eyed River-martin Eurochelidon sirintarae has

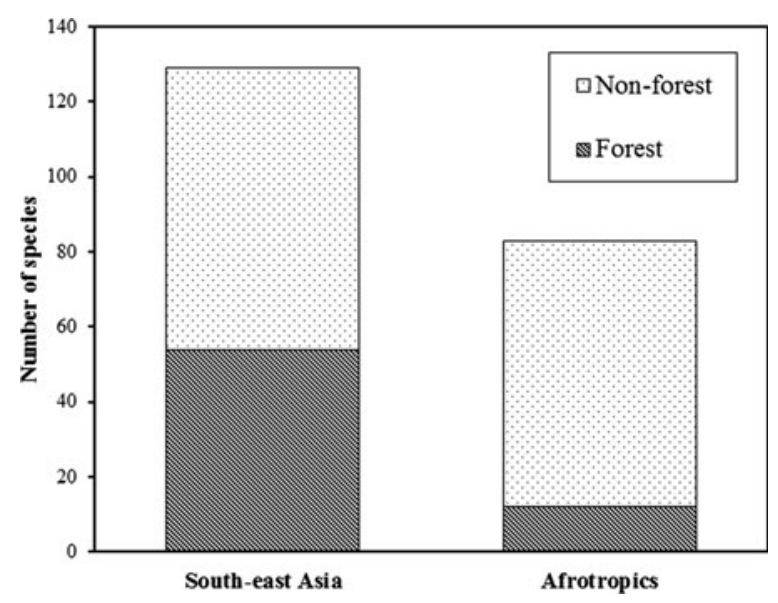

Figure 6. Bar chart showing relative proportion of forest-dependent and non-forest dependent migratory songbirds in South-East Asia and the Afrotropics (i.e. West and East Africa). 
not been reliably recorded for three decades and may be extinct (BirdLife International 2013). Since 1994, six threatened or Near Threatened species have been uplisted while only one was downlisted (Marsh Grassbird Locustella pryeri). A further 15 species threatened since 1994 showed no improvement in status, suggesting that conservation efforts for these species had limited effects in stemming their declines. While the number of 'Vulnerable' species has dropped, this has been offset by an increase in species recognised as 'Endangered' in the past two years (Figure 7).

Bird families with high proportions of declining species have members that are dependent on broadleaved evergreen forests (e.g. Pittidae) or freshwater wetlands as wintering grounds (e.g. Acrocephalidae, Locustellidae) (Table $\mathrm{S}_{3}$ ), as well as some species of scrubby open habitats (e.g. Moores 2013). Rapid land use change across the region suggests that a serious and very apparent threat to migratory songbirds is habitat loss, given that migratory species spend more time in the tropical wintering habitats than elsewhere (Sherry and Holmes 1995). While hunting can affect songbirds at localised spots along the migration trajectory, utilisation of different habitat types across breeding, stop-over and wintering areas means migratory bird populations are susceptible, and thus limited by conditions in multiple sites along its migratory trajectory (Newton 2004). In the context of the East Asian Flyway, changing habitat conditions at migration stop-over sites (Wang et al. 1998) and in the wintering grounds (Dale and Hansen 2013) are of particular concern given much documented habitat loss in East (e.g. Moores 2012) or South-East Asia (Table 5).

\section{Declining trends of East Asian migratory songbirds}

The long term population trends and rates of decline (if any) of migratory songbirds in the East Asian Flyway remain very poorly known. This is unlike the African-European flyway where comprehensive and established monitoring schemes across multiple countries in Europe (e.g. Pan European Common Bird Monitoring Scheme) and the availability of large datasets (e.g. Birds in Europe database) has allowed clear trends in declines of migratory songbirds to be identified, even at the continental level (Vickery et al. 2014). In particular, many European countries also have large-scale demographic monitoring programmes using standardised mist-netting or nest monitoring to determine survival,

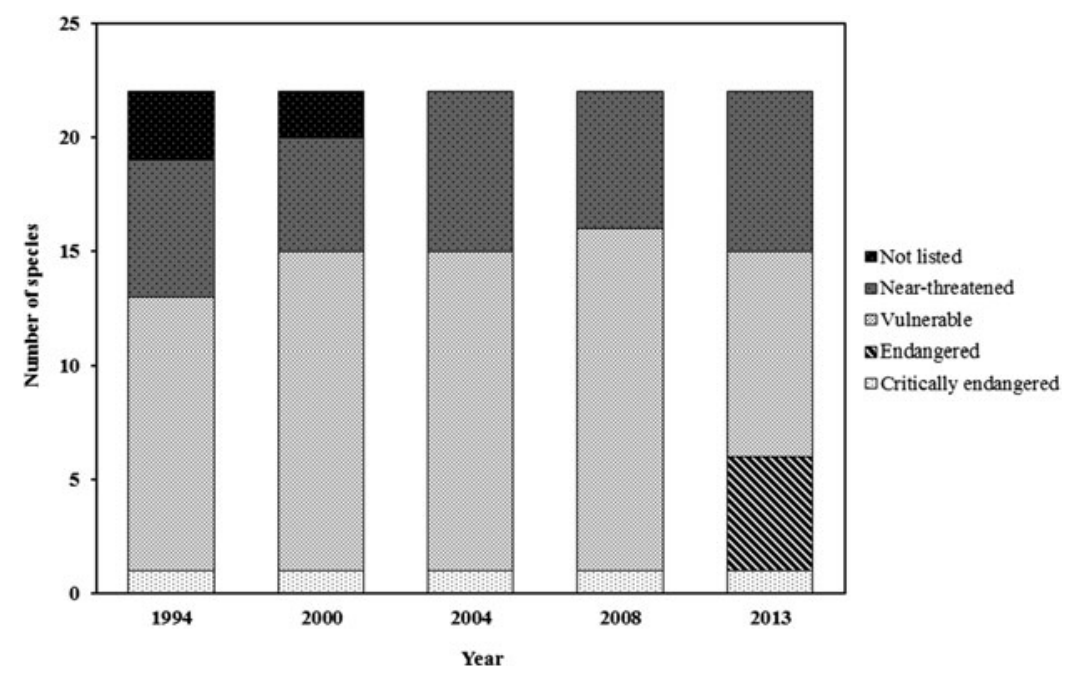

Figure 7. Bar chart showing change in threat status of migratory songbirds in the East Asian migratory system from 1994 to 2013 . Since 1994, all listed species have either showed no change in status or were uplisted to a higher threat category while only one (Marsh Grassbird Locustella pryeri) was downlisted to a lower threat category within this period. 
productivity and recruitment rates which can then be used to explain changes in bird populations. Such coordinated databases and programmes are unavailable for East or South-East Asia. However, rapid deforestation and agricultural expansion across much of South-East Asia (Sodhi et al. 2010), increasing deforestation and degradation of temperate forests in Mongolia and eastern Russia by logging, mining and fires (Kondrashov 2004, Salovarov and Kuznetsova 2006, Bradshaw et al. 2009, Gombobaatar et al. 2011) and high levels of hunting (e.g. Alonzo-Pasicolan 1992, Liang et al. 2013) logically implies that many migratory songbirds must suffer some levels of decline. Scattered studies at the local or national scale have also identified declines for some migratory songbirds.

In Japan where abundance and occurrence data of summer breeding songbirds are available, tropical (i.e. South-East Asian) wintering species like Japanese Paradise-flycatcher T. atrocaudata exhibited clear declines (Hirano 1996, Higuchi and Morishita 1999) or even disappeared completely from sites while non-migrants were seemingly unaffected (Yamamoto and Seto 1997). Similarly, a number of long-distance, tropical migrants like Eastern Crowned Warbler P. coronatus and Yellow-breasted Bunting have also shown some declines in South Korea (Moores 2012, 2013). In Mongolia, the decline of some migratory songbirds, including the Tree Pipit Anthus trivialis has prompted its red-listing in the national conservation action plan (Gombobaatar et al. 2011). In particular, the rapid decline of the Rustic Bunting, a species dependent on agricultural areas and woodland in winter is now corroborated by data and field surveys across its Eurasian distribution in Finland (Laaksonen and Lehikoinen 2013), Japan (Ozaki 2008) and South Korea (Moores 2012). In South-East Asia, Round (2010) has also found possible declines in abundances of migrating Tiger Shrikes Lanius tigrinus in Thailand, relative to other songbird migrants. Not surprisingly, long-distance migration is now established as an attribute of declining songbirds (Amano and Yamaura 2007, Bairlein and Schaub 2009).

\section{Threats faced by migratory songbirds}

The threats faced by migratory songbirds are diverse and may interact in complex ways to drive declines across different parts of the world. For instance, Newton (2004) noted that the decline of Nearctic-Neotropical and African-European migrants have differing causes. While Afrotropical migrants from Europe have declined due to fluctuating climatic conditions in the Sahel where many species overwinter; habitat loss in breeding, wintering and stop-over sites (Sanderson et al. 2006, Vickery et al. 2014), and hunting in the Mediterranean rim (McCulloch et al. 1992), North American migrant declines have been largely attributed to forest loss and fragmentation in the wintering range (Sherry and Holmes 1995, Askins 2000, Rappole et al. 2003). Unlike either North America or Europe, we are unaware of published studies that have examined how different threats have affected songbird migrants along the East Asian migratory system although regional reviews do exist (e.g. Moores 2012). Available quantitative and anecdotal evidence suggests that habitat loss and hunting are the most significant threats. Other threats like invasive species and collision with structures are recognised (Figure 8), but with less evidence of their impacts across the region.

\section{Habitat loss and degradation}

Habitat loss, particularly of broadleaved evergreen forests which are increasingly clear-cut, fragmented, or degraded by logging at large scales in South-East Asia is well known (e.g. Linkie et al. 2004, Miettinen et al. 2010) and its impacts on biodiversity patterns, especially resident bird communities are well documented (e.g. Sodhi et al. 2010). However, the impacts of this habitat loss on migratory songbirds and their decline are not well understood. This is because there are few studies on the diversity, status or wintering ecology of flycatchers, warblers, robins and thrushes across much of the region, even though studies of resident bird communities do document some migratory songbirds (e.g. McClure 1967) while some mist-netting studies have examined the wintering ecology of common migrants like Great Reed-warbler A. arundinaceus (e.g. Nisbet and Medway 1974) and Brown Shrike (Medway 1970). Countrywide reviews like Lim and Lim (2009) 

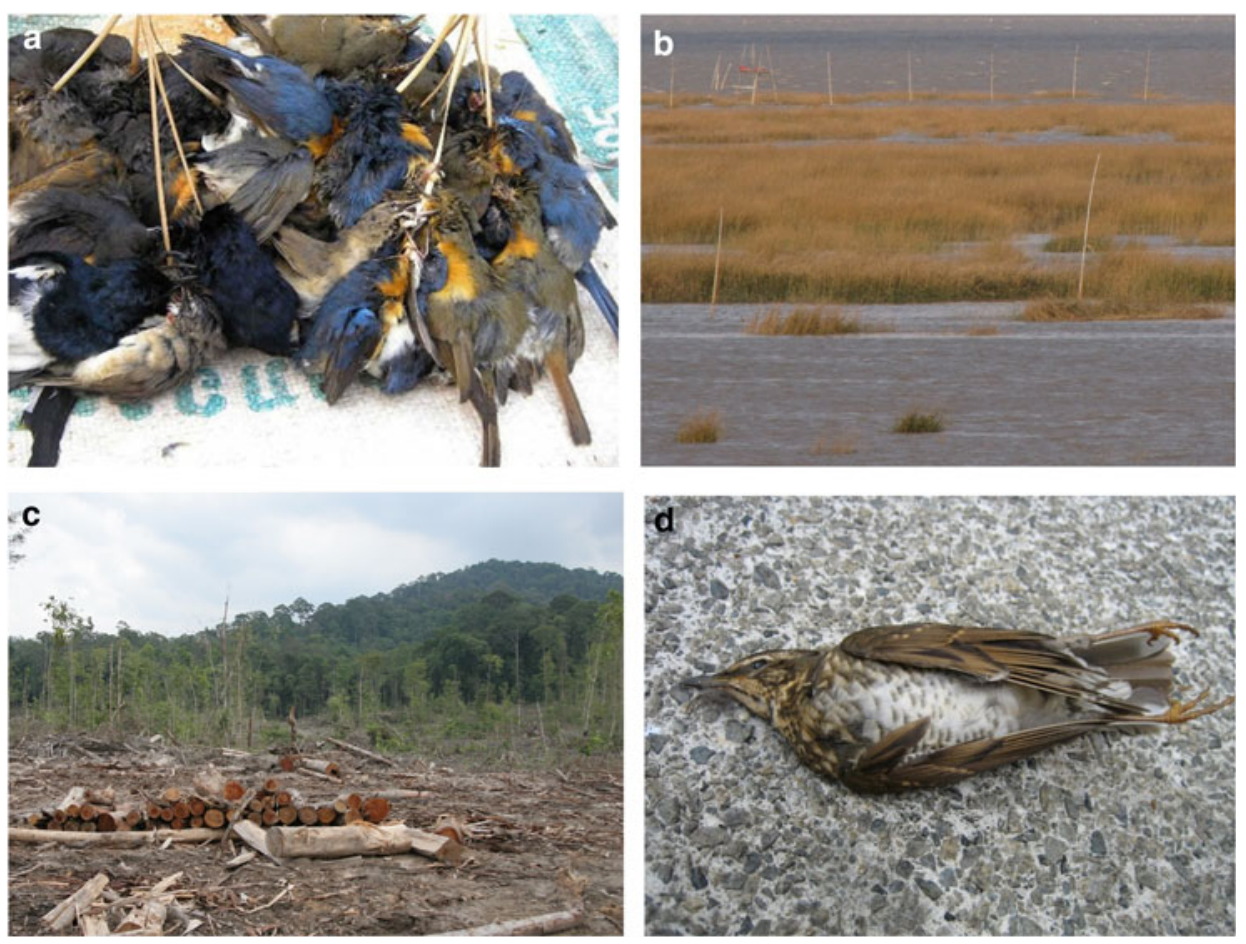

Figure 8. Key threats faced by migratory songbirds in the East Asian Migratory Flyway: a) Hunting of songbirds for food: dead songbirds including some migratory species at a market in Vientiane, Lao PDR (Photo: Andrew Chow) b) Invasive species: Smooth cordgrass Spartina alternifolia on Jiangsu coast, China (Photo: Ding Li Yong), c) Habitat loss: clearance of lowland rainforests in peninsular Malaysia (Photo: Ding Li Yong), d) Collision with man-made structures: dead Siberian Thrush Zoothera sibirica in urban area in Singapore (Photo: Felix Wong).

have also reported declining trends for some migrant songbirds in Singapore, but the limited spatial context of these findings mean that they do not necessarily reflect distribution-wide changes as decline patterns may also arise from fluctuations due to other factors (Newton 2004). Clearly, this lack of knowledge is of concern because the loss of wintering habitat has been shown to impact population declines more than habitat loss in breeding areas (Sutherland 1996).

Given that many migratory songbirds in South-East Asia and south China depend on broadleaved evergreen forests as wintering habitat (see Tables 4 and 5), the rapid clearance and degradation of lowland and submontane rainforests across Cambodia, Sumatra, Borneo and the Philippines (Table 5) indicate that wintering songbirds there have lost large proportions of intact wintering habitats. Six forest-dependent migratory songbirds are already listed as globally threatened (Table 6). Furthermore, currently 'Least Concern' species that winter predominantly in Sundaic forests like Narcissus Flycatcher, Siberian Blue Robin and Blue-and-white Flycatcher Cyanoptila cyanomelana may also have suffered declines as a result of widespread habitat loss across western Indonesia and Malaysia. A few species like the 'Vulnerable' Rufous-headed Robin Luscinia ruficeps is hypothesized to winter in South-East Asian forests but its winter range remains unknown (Mahood et al. 2013a). On the contrary, the implementation of new forestry policies in China, particularly the Natural Forest Protection Plan (Li et al. 2007, IUCN-WCPA 2011) is expected increase forest cover across parts of eastern and southern China and may benefit some forestdependent species, at least as demonstrated in Hong Kong (Kwok and Corlett 2000). 


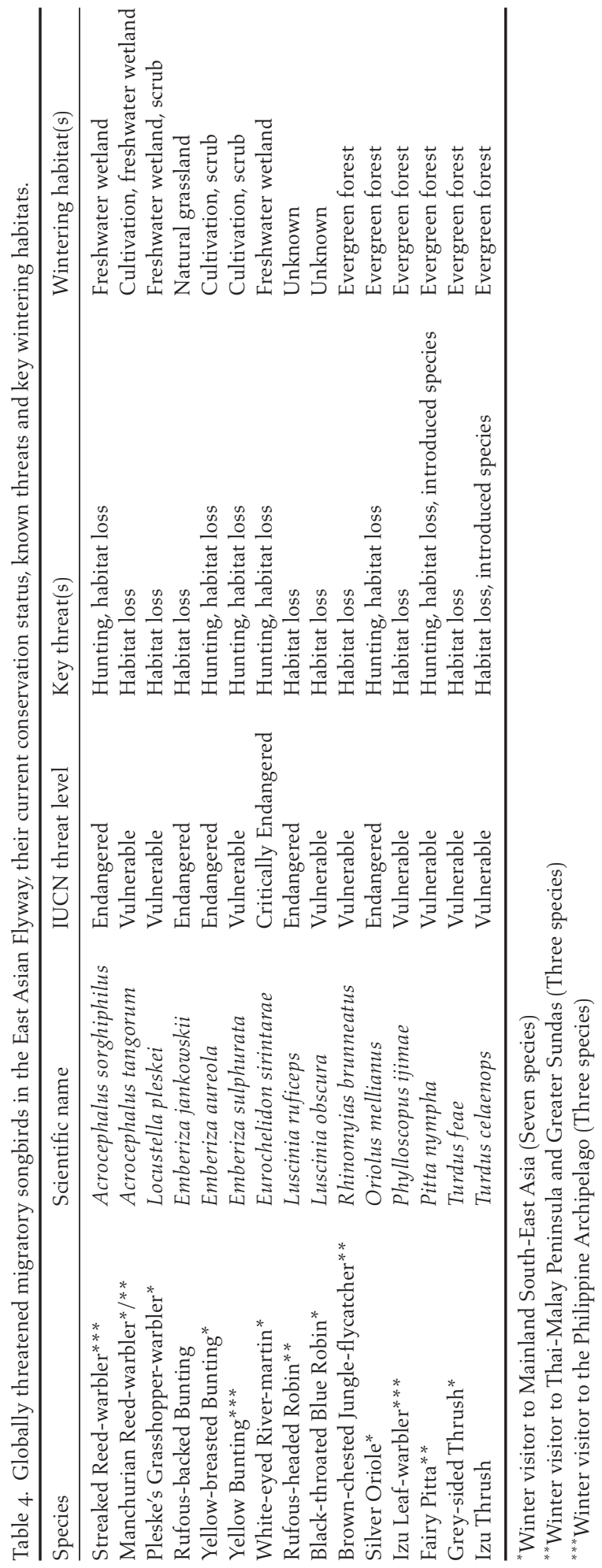




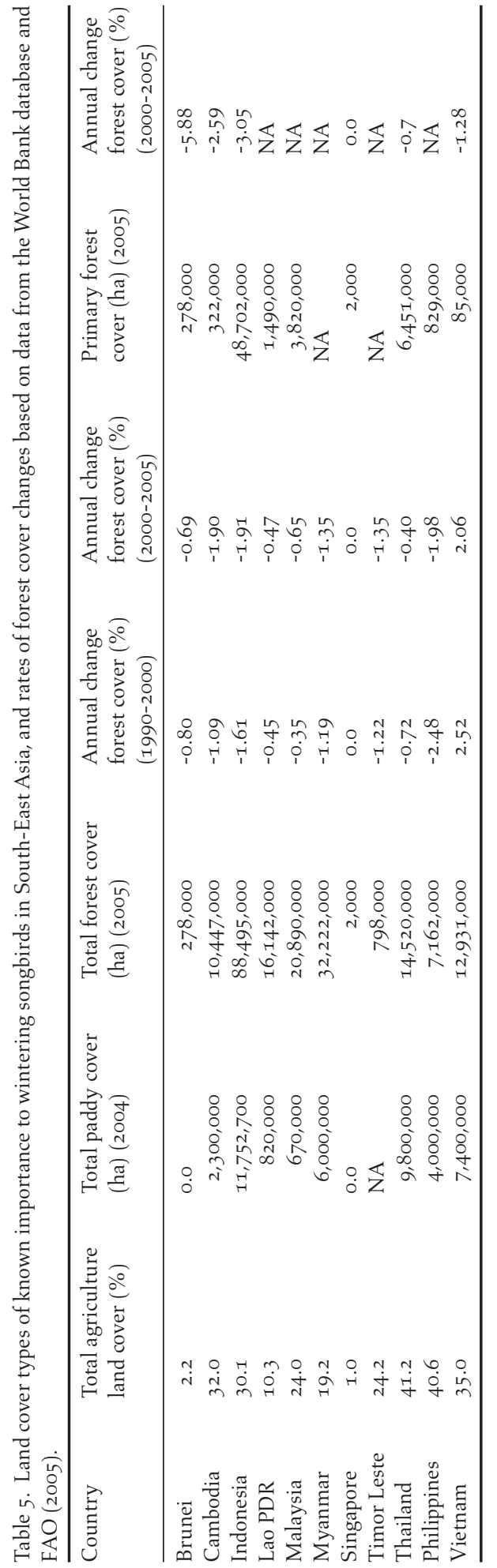


Table 6. Known sites of importance to songbird migration along the East Asian Flyway where surveys and bird-banding exercises have been carried out, or suitable for future research and monitoring.

\begin{tabular}{|c|c|c|}
\hline Country & Site name and administrative region & Coordinates \\
\hline \multirow[t]{3}{*}{ Russia } & Muraviovka Park, Amur Oblast & $49^{\circ} 87^{\prime} \mathrm{N}, 127^{\circ} 7 \mathrm{O}^{\prime} \mathrm{E}$ \\
\hline & Bolshekhekhtsirsky Reserve, Khabarovsk Oblast & $48^{\circ} 11^{\prime} \mathrm{N}, 134^{\circ} 40^{\prime} \mathrm{E}$ \\
\hline & Litovka River, Nakhodka City, Primorsky Krai & $42^{\circ} 96^{\prime} \mathrm{N}, 132^{\circ} 88^{\prime} \mathrm{E}$ \\
\hline \multirow[t]{3}{*}{ Japan } & Hegura-jima, Ishikawa (Island) & $37^{\circ} 51^{\prime} \mathrm{N}, 136^{\circ} 55^{\prime} \mathrm{E}$ \\
\hline & Mishima, Yamaguchi (Island) & $34^{\circ} 77^{\prime} \mathrm{N}, 131^{\circ} 14^{\prime} \mathrm{E}$ \\
\hline & Ryukyu-shoto, Kagoshima (Islands) & $26^{\circ} 30^{\prime} \mathrm{N}, 128^{\circ} \mathrm{Oo}^{\prime} \mathrm{E}$ \\
\hline \multirow[t]{4}{*}{ South Korea } & Socheong-do, Incheon (Island) & $37^{\circ} 46^{\prime} \mathrm{N}, 124^{\circ} 44^{\prime} \mathrm{E}$ \\
\hline & Eocheong-do, Jeonbuk (Island) & $36^{\circ} 7 \mathrm{O}^{\prime} \mathrm{N}, 125^{\circ} 5^{\prime} \mathrm{E}$ \\
\hline & Heuksan-do, Jeonnam (Island) & $34^{\circ} 67^{\prime} \mathrm{N}, 125^{\circ} 42^{\prime} \mathrm{E}$ \\
\hline & Hong-do, Jeonnam (Island) & $34^{\circ} 42^{\prime} \mathrm{N}, 125^{\circ} 11^{\prime} \mathrm{E}$ \\
\hline \multirow[t]{9}{*}{ China } & Beidaihe, Hebei & $39^{\circ} 50^{\prime} \mathrm{N}, 119^{\circ} 29^{\prime} \mathrm{E}$ \\
\hline & Laotieshan, Liaoning & $38^{\circ} 46^{\prime} \mathrm{N}, 121^{\circ} 11^{\prime} \mathrm{E}$ \\
\hline & Rudong, Jiangsu & $32^{\circ} 18^{\prime} \mathrm{N}, 121^{\circ} 11^{\prime} \mathrm{E}$ \\
\hline & Xiaoyangshan, Zhejiang (Island) & $30^{\circ} 62^{\prime} \mathrm{N}, 122^{\circ} \mathrm{o} 6^{\prime} \mathrm{E}$ \\
\hline & Daniao-ao, Hunan & $27^{\circ} \mathrm{O} 6^{\prime} \mathrm{N}, 111^{\circ} \mathrm{O} I^{\prime} \mathrm{E}$ \\
\hline & Longqingguan, Yunnan & $25^{\circ} 18^{\prime} \mathrm{N}, 100^{\circ} 21^{\prime} \mathrm{E}$ \\
\hline & Ailaoshan, Yunnan & $24^{\circ} 53^{\prime} \mathrm{N}, 100^{\circ} 19^{\prime} \mathrm{E}$ \\
\hline & Fenghuangshan, Yunnan & $23^{\circ} 57^{\prime} \mathrm{N}, \mathrm{IOI}^{\circ} 3 \mathrm{O}^{\prime} \mathrm{E}$ \\
\hline & Po Toi, Hong Kong (Island) & $22^{\circ} 17^{\prime} \mathrm{N}, 114^{\circ} 27^{\prime} \mathrm{E}$ \\
\hline \multirow[t]{2}{*}{ Vietnam } & Hanoi City & $21^{\circ} 20^{\prime} \mathrm{N}, 105^{\circ} 51^{\prime} \mathrm{E}$ \\
\hline & Con Lu, Nam Định (Island) & $20^{\circ} 21^{\prime} \mathrm{N}, 106^{\circ} 55^{\prime} \mathrm{E}$ \\
\hline \multirow[t]{2}{*}{ Philippines } & Babuyan Islands, Cagayan (Islands) & $19^{\circ} 34^{\prime} \mathrm{N}, 121^{\circ} 48^{\prime} \mathrm{E}$ \\
\hline & Dalton's Pass, Nueva Vizcaya & $16^{\circ} 73^{\prime} \mathrm{N}, 120^{\circ} 55^{\prime} \mathrm{E}$ \\
\hline Thailand & Ko Man Nai, Rayong (Island) & $12^{\circ} \mathrm{OI}^{\prime} \mathrm{N}, 102^{\circ} 28^{\prime} \mathrm{E}$ \\
\hline \multirow[t]{3}{*}{ Malaysia } & Mantanani and Mengalum, Sabah (Islands) & $6^{\circ} 20^{\prime} \mathrm{N}, 115^{\circ} 59^{\prime} \mathrm{E}$ \\
\hline & Fraser's Hill, Pahang & $3^{\circ} 73^{\prime} \mathrm{N}, 101^{\circ} 73^{\prime} \mathrm{E}$ \\
\hline & One Fathom Bank, Selangor (Island) & $2^{\circ} 53^{\prime} \mathrm{N}, 100^{\circ} 59^{\prime} \mathrm{E}$ \\
\hline \multirow[t]{2}{*}{ Singapore } & Bidadari Park & $1^{\circ} 34^{\prime} \mathrm{N}, 103^{\circ} 87^{\prime} \mathrm{E}$ \\
\hline & St John's (Island) & $1^{\circ} 13^{\prime} \mathrm{N}, 103^{\circ} 50^{\prime} \mathrm{E}$ \\
\hline
\end{tabular}

Many songbirds that breed or winter in wetland habitats will also be affected by land use change across their distributions. While some species of bush- and reed-warblers can utilise human-modified landscapes such as paddyfields (Wells 2006), natural wetlands like freshwater and coastal marshes, and seasonally-flooded grasslands remain important as wintering habitats for most Acrocephalus and Locustella warblers, and are increasingly threatened by drainage, reclamation or conversion to agricultural land. The 'Vulnerable' Streaked Reed-warbler A. sorghiphilus, for example is known to winter only in the Candaba marsh in central Luzon, a site increasingly drained for agricultural expansion (BirdLife International 2013), as are similar wetlands in the Philippines. Likewise, the 'Vulnerable' Manchurian Reed-warbler A. tangorum winters mostly in Phragmites reedbeds of Khao Sam Roi Yot National Park in Thailand and flooded grasslands by Tonle Sap, Cambodia (Sam 1999, Round and Rumsey 2003). Habitats at both sites are being encroached upon (BirdLife International 2013). Its recent discovery in northern Peninsular Malaysia (Bakewell 2013) further reflects the poor state of knowledge of its winter distribution, and a similar scenario applies to Pleske's Grasshopper-warbler Locustella pleskei.

\section{Hunting}

One major threat shared by migratory songbirds in the East Asian and the African-European migratory systems is widespread hunting, an especially visible issue around the Mediterranean rim (e.g. McCulloch et al. 1992, Vickery et al. 2014) although the underlying motivations are 
different. While quantitative data are lacking, hunting of wild birds for food in rural areas and the pet trade remains rampant across many parts of South-East Asia (e.g. Shepherd 2006, Dinata et al. 2008), mainland China (Feng 2012, Li 2012, Liang et al. 2013) and until recently, Taiwan and the Ryukyus (Severinghaus 1996). These hunting pressures have been linked to the rapid decline of the Yellow-breasted Bunting, resulting in its IUCN threat status from being upgraded from 'Least Concern' to 'Vulnerable' in less than one decade (Chan 2004, BirdLife International 2013, $\mathrm{Li}$ 2013). The combined impact of harvesting for various reasons increases net mortality rates and can reduce returning populations of songbirds in spring considerably (Severinghaus 1996), which has been shown in the declines detected during spring surveys in the breeding grounds of some species, e.g. Rustic Bunting (Dale and Hansen 2013).

In parts of Cambodia, migratory songbirds including various swallows, Black-browed A. bistrigiceps and Great Reed-warblers are trapped in the tens to hundreds of thousands for religious 'mercy releases' (Gilbert et al. 2012) with high mortalities resulting. Similar practices are reported in Thailand where thousands of Yellow-breasted Buntings were caught for release (McClure and Chaiyaphun 1971), as well as in Hong Kong and Taiwan (Severinghaus and Chi 1999). Difficulty in enforcement of wildlife protection laws across the region (Corlett 2007), especially rural areas complicates the hunting problem. In western Indonesia where bird-keeping is a popular and deeprooted practice, some long-distance migrants such as Siberian Thrush Zoothera sibirica, Orangeheaded Thrush Z. citrina, Chestnut-cheeked Starling Sturnus philippensis and Purple-backed Starling S. sturninus are trapped in large numbers for sale in bird markets (Nash 1993, Shepherd et al. 2004, Shepherd 2006, Wong 2014). In a survey of the bird trade across South-East Asia and Hong Kong, Nash (1993) reported at least 30 species which are migratory songbirds, including a number of thrushes and flycatchers, while Purple-backed Starling occurred in more than half of surveys of bird shops conducted across Indonesia. Likewise, various migratory finches, warblers and thrushes are also caught for the pet trade in China where a tradition of keeping birds exist (Townsend 2013).

Deliberate or opportunistic trapping of birds for food remains rampant and prevalent across South-East Asia and south China, and is fuelled largely by local (e.g. Iqbal et al. 2014) or cross-border demands (e.g. Butler 2009). The easy availability of mist-nets (e.g. Bakewell 2007, Townsend 2012) facilitates this. The recovery of ringed Rustic Buntings from bird markets in China (Fransson et al. 2007) and recent documentation of mass hunting of Eyebrowed Thrush Turdus obscurus in Sumatra (Iqbal et al. 2014) offers clear evidence of these hunting pressures. At the well-documented Dalton's Pass, northern Luzon, local people continue to trap thousands of migrating birds at night for consumption, using lighted traps (Alonzo-Pasicolan 1992), including threatened songbirds like Streaked Reed-warbler (BirdLife International 2013). Similar hunting approaches targeting migrating songbirds have also been documented across many parts of southern China, especially in Yunnan, Hunan and Jiangxi provinces (Xiao et al. 2005, Yang et al. 2009, Anon 2012). Large-scale trapping of birds in general is endemic in parts of south China, particularly Hainan where many species, including migrant songbirds are hunted by local people for meat and medicine using various methods (Liang et al. 2013). The situation may be even worse in South-East Asia, particularly in the Lao PDR where once subsistence exploitation of wildlife for food has swollen to massive scale hunting to fulfil cross-border demands of bushmeat (Butler 2009). While the impacts of hunting on migratory songbird populations across the East Asian migratory system have not been well-studied, they have been linked to the declines of some species, especially a number of buntings (e.g. Dale and Hansen 2013).

\section{Other key threats}

Two other poorly documented threats to migratory songbirds in East Asia are invasive species and collisions with man-made structures in cities across the region. Collision with man-made structures is known to be responsible for high mortalities in migratory songbirds in North America and Europe (Rich and Longcore 2005, Hüppop et al. 2006, Anderson 2011). Unlike other threats, collisions with glass are known to kill migrants non-selectively, and irrespective of fitness 
(Kirby 2010), detrimentally affecting songbird populations on migration in North America (Loss et al. 2014). Moreover, songbirds migrating at night are known to be strongly attracted to sources of artificial light, resulting in collisions which can lead to injury or death (Ogden 1996, Round 2010). A few examples are available from the East Asian flyway. On Hong-do Island, a key stop-over site for migrating birds off the South Korean coast, collisions with windows and artificial structures were found to be the primary cause of bird mortality and especially so for migrating buntings, pipits and white-eyes (Bing et al. 2012). Window strikes as well as traffic accidents were also the most common cause of mortality of Fairy Pittas on Jeju Island in Korea (Kim et al. 2013). In eastern Hokkaido, Japan, individuals from 63 species were reported to be killed by window collisions from 1980 to 1997, with increased mortality during the migration period (Yanagawa and Shibuya 1998). In South-East Asia, data collected from birdwatcher reports in Singapore revealed higher mortalities of birds due to collisions with man-made structures in built-up areas (Low et al. in prep, Yong et al. 2013) and involves many migratory songbirds like pittas, thrushes, warblers and flycatchers (Low et al. in prep). Since the migration fronts of many songbirds traverse lighted offshore oil platforms during sea crossings (Simpson $1983 \mathrm{~b}$ ) and some of Asia's largest cities which are extensively lit at night and have many high structures, especially Shanghai, Guangzhou and Hong Kong (China), Hanoi (Vietnam), Bangkok (Thailand) and Singapore, resulting mortalities may be very high. The increasing ubiquity of wind turbines, especially along the Chinese Yellow Sea coast (Chen 2009), a region important to migrating birds, could potentially worsen the problem of collisions (e.g. Hüppop et al. 2006).

Lastly, the impact of how invasive plants and animals affect stop-over or wintering songbirds across the region has been little addressed by studies, but available evidence shows that invasive species can prey on, compete with or modify habitats of migratory songbirds. We provide two examples: invasive corvids and plants. The invasive House Crow Corvus splendens, a native of the Indian Subcontinent but established in Peninsular Malaysia and Singapore (Sodhi and Sharp 2006), is known to opportunistically prey on songbird migrants based on casual observations in Singapore (D. L. Yong unpubl.data). Along with native crows, Eurasian Magpies Pica pica that have been introduced from mainland Korea to Jeju Island are also reported as nest predators of the Fairy Pitta (Kim et al. 2013). In coastal marshes of Shanghai municipality and Jiangsu, east China, the invasive cordgrass Spartina alterniflora is increasingly outcompeting and replacing beds of native Phragmites and reed species (Xie and Gao 2013), potentially resulting in habitat loss for wintering songbirds. By 2002, this invasive grass already covered 112,000 ha of China's east coast (Gan et al. 2010). At Chongming island, Shanghai, habitat dominated by Spartina was found to support lower food resources (e.g. arthropods), bird diversity and abundance of four wintering buntings known to be dependent on wetlands, including the near-threatened Ochre-rumped Bunting E. yessoensis (Gan et al. 2010). Similar trends are documented for wintering buntings in shoal-wetlands in the Yangtze delta (Ma et al. 2007).

In general, the complex interaction of diverse threats, particularly habitat loss and degradation occurring in combination across passage sites, the wintering and breeding ranges puts many migratory songbird species at risk. Given that the effects of recent climate change are likely to increasingly disrupt the breeding cycle or migratory activity of these passerines (Koike and Higuchi 2002, Both et al. 2006, Harris et al. 2013), it is clear that there is an urgent need for more empirical data on migratory songbirds, to inform conservation priorities and decisions. In the next section we identify key research and conservation priorities for migratory songbirds in the East Asian Flyway.

\section{Conservation and research priorities}

\section{Research on migratory songbird ecology and survival}

Populations of many migrant songbirds are limited in part by conditions in winter (Sherry and Holmes 1996, Norris et al. 2004), which can in turn affect breeding and reproductive output in 
spring (Holmes 2007). Effective conservation and management therefore need to take these limiting processes, patterns and dynamics into consideration (Holmes 2007). Since wintering distributions and density, habitat usage, demographics and survival rates of many songbirds in this region remain unclear, as are the underlying drivers of decline, a conservation priority is thus to first establish what and where these key wintering habitats are, and document the assemblages and population patterns of songbirds in them, especially across the stop-over/wintering zone in South-East Asia and southern China. Additionally, there is a need for concerted efforts to identify wintering ranges of the most poorly known songbirds in the region. Sampling the diversity, abundance and demographics of songbird migrants over the long term (Newton 2004, Holmes 2007, Round 2010) will be important for detecting ecologically significant trends or fluctuations that indicate wider population patterns, which can help identify causes of decline. Carefully designed field surveys or bird banding exercises in the right places, and at appropriate time and spatial scales can obtain these data in a cost-effective way, and are already in place in few parts of South-East Asia (e.g. Ko Man Nai, Thailand) as well as China, Russia, South Korea and Japan. Many of these survey sites are likely to involve small islands or continental sites containing known concentrations of migratory songbirds (Table 6, Figure 1), which can be sampled by a combination of judicious bird banding (e.g. Ozaki 2008, Nam et al. 2011) and visual surveys of abundance using points or transects (e.g. Moores 2012). Research and monitoring at stop-over or wintering sites must also be complemented by similar activities at breeding sites in East Asia (e.g. Hirano 1996). Adaptive monitoring programmes could enable meaningful population trends to be detected if these are carried out with a standardised methodology, while taking into consideration longer-term uncertainties in the monitoring process.

Although funding for surveys is scarce in many South-East Asian countries, a number of funding bodies and charities now provide grants to local conservationists and researchers, especially those in developing countries, and can be used to support field surveys on occurrence and abundance of migratory songbirds in poorly known areas. In fact, data on other migratory species, especially raptors and the endangered Spoon-billed Sandpiper Eurynorhynchus pygmaeus have been collected in South-East Asia (e.g. DeCandido et al. 2004, Bird et al. 2010) by birdwatchers in collaboration with local conservationists through these means.

\section{Research on migration routes and connectivity}

Although standardised bird banding (e.g. McClure 1974) and to some extent, satellite tracking (e.g. Higuchi 2013) has been effectively used to gather data on aspects of stop-over ecology in East and South-East Asia, many facets of the migration routes, connectivity, and stop-over site usage of long-distance migratory songbirds across East Asia remain unknown and for some species, their entire wintering grounds remain unclear, especially the difficult to identify Phylloscopus warblers (Yap et al. 2014). Mass ringing can give an indication of movements and migratory connectivity for a few species that can be trapped in large numbers, but miniaturisation in tracking technologies means that it is now possible to study movement of songbirds lighter than 20-30 $\mathrm{g}$ using geo-locators and archival Global Positioning System (GPS) tags (e.g. McKinnon et al. 2013). The drawbacks of using these units are the low recovery rates for species that do not show good site fidelity, high costs of procurement and location accuracy problems, but the technology is advancing quickly. These methods can also be used in conjunction with molecular genetic data and stable isotope ratio analysis (Marra et al. 1998, Holmes 2007) to learn about migration routes, flight rates, wintering sites and migratory connectivity.

Finally, radar technology has been used in some stop-over ecology studies to show the relative importance of different habitats to migrant songbirds (e.g. Ruth et al. 2012) and diverse aspects of bird migration movements under different weather and light conditions (e.g. Bruderer 1997). While there are known limitations, radar technology can still be used to gather data on migration patterns and movements at night or during poor weather, and to complement data gathered from other means. 


\section{Legal frameworks for conserving migratory birds}

Given the large geographic ranges of migratory birds spanning multiple countries, effective conservation can be challenging (Kirby 2010, Bauer and Hoye 2014) and must protect all habitats used during the annual cycle to be successful (Norris et al. 2004). At a regional to continental scale, national government-linked conservation bodies and environmental ministries need to recognise that the conservation of migratory species traverses national boundaries, and enact legislation that explicitly protects migratory species (Sands 2003) in addition to existing wildlife protection laws for sedentary or restricted-range species. Coordination of conservation efforts and knowledge sharing between the territories in the East Asian migratory system is needed if conservation actions are to be effective, and existing initiatives like the Partnership for the East Asian-Australian Flyway (see EAAFP 2012) do facilitate these actions to some extent even though the scope of this initiative covers mainly waterbirds at present.

Unlike raptors, waders and large waterbirds such as cranes, the poor visibility of songbirds means that they can be easily overlooked not only by conservationists, but also by the very policies designed to conserve migratory species in general. The Convention on the Conservation of Migratory Species of Wild Animals (CMS) or Bonn Convention, an important global agreement under the purview of the United Nations Environment Programme (UNEP) provides a legal framework and comprehensive guidelines for conserving migratory species worldwide (CMS 2014), but targets mostly large charismatic taxa like mammals, sea- and waterbirds (Kirby 2010). Thus far, the only Memorandum of Understanding (MoU) concluded under the CMS for a migratory songbird is on the Aquatic Warbler Acrocephalus paludicola, an African-European migrant. Besides its limited scope and coverage, only 119 parties had ratified the CMS as of February 2014 (CMS 2014), and this total excludes the majority of states along the East Asian-Australasian Flyway. The lack of ratification by states with territories overlapping with the breeding, stop-over or wintering ranges of so many migratory species continues to pose a stumbling block for transboundary coordination of conservation activities. Furthermore, its slow growth in membership suggests that the impact of CMS on conserving migratory species is very limited. Given this, many of the species listed in CMS Appendix I remain symbolic (de Klemm 1994).

Filling in these policy gaps and discrepancies may be possible with the conclusion of new Memoranda of Understanding and other legally binding agreements targeting threatened East Asian migratory songbirds. Additionally, some of the loopholes in these existing legal frameworks can be partly addressed by bilateral agreements on migratory species. For example, China and Russia, two of the most important countries in the flyway for breeding, stop over and overwintering of many songbird migrants signed the China-Russia Migratory Bird Agreement (CRMBA) in 2012, on top of existing agreements for Japan and South Korea (Boer et al. 1998, EAAFP 2012). Similar agreements exist between Japan and the U.S.A (U.S. Fish and Wildlife Service 2014), and between other Asian countries (see Boer et al. 1998) although follow-up actions for conservation remain relatively limited. Furthermore, geopolitical disputes between countries in the East China Sea and Yellow Sea region (e.g. Valencia 2007), an important area for bird migration, may potentially complicate any transboundary arrangement to conserve migratory birds.

At the national level, better enforcement of existing wildlife protection laws will be needed to protect migratory birds and wildlife in general, although this has been plagued by limited government funding, corruption and poverty in many Asian countries (Corlett 2007). National and regional wildlife protection agencies will need to review and include listings of migratory songbirds in existing wildlife enactments, given that priorities in many listings have tended to focus on non-migratory, resident species (e.g. Sabah Wildlife Department 2004). These actions will be of greater importance in China, Indonesia, the Philippines, Lao PDR, Cambodia and Thailand where migratory songbirds have been heavily harvested for the pet bird trade, food or religious uses. 


\section{Conservation planning}

Conservation of migratory species can be successful if adequate habitat is protected at breeding, stop-over and wintering sites. The extensive network of reserves across countries in the East Asian Flyway, particularly East Asia where protected areas cover about $16 \%$ of the region (MacKinnon et al. 2005), means that most migratory songbirds have some part of their distribution protected, but to varying extents. If sites important to stop-over or wintering songbirds are found to overlap with existing protected areas, then the priority will be to step up or maintain protection measures like enforcement of regulations to manage disturbance. If these sites are unprotected, they then should be evaluated for other biodiversity elements and identified under regional/national conservation frameworks for formal conservation actions. Inevitably, conserving songbird migrants will involve protecting patches of stop-over habitat (Sheehy et al. 2011), some of little value to other biodiversity (e.g. Yong 2013). In particular, studies using habitat and population parameters (e.g. density dependence) of North American migratory songbirds have developed models to optimise resource investments to conserve migratory songbirds (e.g. Sheehy et al. 2011), which in turn can inform conservation strategies targeting wintering, breeding and stop-over sites. These findings can provide insights in developing transboundary conservation plans targeting songbird migrants in East and South-East Asia if critical ecological information is available, and may be useful for initiating future MoUs for threatened species. Finally, since many wintering songbirds are dependent on tropical forests that are also of conservation importance to other biodiversity, we acknowledge that effective protection of these landscapes is likely to benefit many migratory songbirds. What remains to be seen is whether resident species which are more readily surveyed can act as effective surrogates for conserving migratory songbirds.

\section{Citizen science, education and the role of birdwatchers}

The number of birdwatchers is rapidly increasing across Asia, especially in mainland China (Ma et al. 2013) and a number of South-East Asian countries (e.g. Thailand, Indonesia, Philippines), given a fast growing middle class. Ma et al. (2013) also report that there are now 36 birdwatching clubs distributed across mainland China while the total number of birdwatchers exceeds 20,000. In Taiwan, South Korea and Japan there is already a well-established tradition of birdwatching, as well as established biodiversity or ornithological institutions: e.g. Migratory Birds Centre in Korea National Park Research Institute (South Korea), Yamashina Institute for Ornithology (Japan). In the Russian Far East, non-governmental organisations like the Amur-Ussuri Centre for Avian Biodiversity support migratory bird research in the region and carry out important ornithological surveys.

Given that many amateur birdwatchers keep lists and records of their observations, much of which are deposited online, or compiled in annual bird reports (China Ornithologists' Society 2008), the collective output of data from birdwatchers if analysed, can reveal ecologically significant changes such as fluctuations in species populations over short time-scales, distribution contractions or expansions, and other temporal trends (Round 2010, Li et al. 2013). Data from birdwatchers have not only contributed to studies like Yamamoto and Seto (1997) and Harris et al. (2013), but have also improved knowledge of the distribution and status of threatened songbird migrants such as the Rufous-headed Robin in Cambodia (Mahood et al. 2013a), Japanese Paradise-flycatcher in Java (Emmanuel and Yordan 2013), and the Brown-chested Jungleflycatcher in north Vietnam (Mahood et al. 2013b) and Singapore (Yong and Liu in press), all migrants with poorly known wintering ranges. While the problem of language barriers across various Asian countries could prove to be an impediment for information-sharing, the 'eBird system' (Wood et al. 2011) could be a good model for transboundary data collection if birdwatchers across the region can be encouraged to participate. One likely pitfall is that distributional records will be biased to heavily visited sites and certain months of the year, while inaccessible areas may remain chronically under-surveyed, as is the case in western Indonesia (Yong and Liu in press), 
Wallacea or Russia's boreal zone. Despite these shortcomings, there is much potential for collaborative research between birdwatchers and researchers in Asia, which unlike Europe or North America, is presently patchily distributed across the continent (Greenwood 2007). Such collaborations would allow researchers to tap into data collected by birdwatching organisations or birdwatchers to better understand migration ecology and identify significant populations, sites and trends for targeted conservation actions.

Finally, the increasing popularity of birdwatching as a pastime across East and South-East Asia means that birdwatchers and their organisations have the knowledge and capacity to increase awareness of migratory bird conservation through their activities to over 1.8 billion people who live in the region. An example of these conservation efforts led by birdwatchers is the 'Asian Bird Fair', which is now held annually across a number of East and South-East Asian countries, and coordinated by respective national birdwatching clubs (e.g. Wild Bird Club of the Philippines, Chinese Wild Bird Federation) (see Birdfair Asia 2011). This is on top of nationallevel birdwatching activities (e.g. China Bird Festival, Thailand Bird Fair; Bird Conservation Society of Thailand 2013) held in the countries across the region. These efforts will surely complement the existing outreach, research and educational work of major conservation organisations such as BirdLife International, and many regional and local non-government conservation organisations.

\section{Supplementary Material}

The supplementary materials for this article can be found at journals.cambridge.org/bci

\section{Acknowledgements}

We wish to thank Ian Newton and Who-Seung Lee who sent us copies of their papers, Andrew Chow and Felix Wong for allowing use of their photographs, Andrew Pierce for comments on passerine migration in Thailand, Makiko Takenaka for songbird declines in Hokkaido, and Alfred Chia for providing data on bird collisions in Singapore. D. L. Yong thanks David B. Lindenmayer for support. Finally, we are grateful to Stephen Garnett and Hiroyoshi Higuchi, both whose constructive comments have helped us to improve the manuscript greatly.

\section{References}

Abe, N. and Kurosawa, O. (1982) A remarkable fall of migrant passerine on the ship. J. Yamashina Inst. Ornithol. 14: 59-67. (In Japanese).

Alerstam, T., Backman, J., Strandberg, R., Gudmundur, A., Gudmundsson, A. H., Henningsson, S. S., Karlsson, H. and Rosen, M. (2008) Great-circle migration of Arctic passerines. Auk 125: 831-838.

Alonzo-Pasicolan, S. (1992) The bird-catchers of Dalton's Pass. Oriental Bird Club Bulletin 15:33-36.

Alström, P., Saitoh, T., Williams, D., Nishiumi, I., Shigeta, Y., Ueda, K., Irestedt, M., Björklund, M. and Olsson, U. (2011) The Arctic Warbler Phylloscopus borealis-three anciently separated cryptic species revealed. Ibis 153: 395-410.

Amano, T. and Yamaura, Y. (2007) Ecological and life-history traits related to range contraction among breeding birds in Japan. Biol. Conserv. 37: 271-282.

Amano, T., Szekely, T., Koyama, K., Amano, H. and Sutherland, W. J. (2010) A framework for monitoring the status of populations: An example from wader populations in the East Asian-Australasian flyway. Biol. Conserv. 143: 2238-2247.

Anderson, P. K. (2011) Wireless telecommunications and night flying birds: We may be sacrificing millions of migrants for convenience, entertainment and profit. Biodiversity 4: 10-17.

Anon. (2007) Preliminary study on bird migration on Po Toi Island (Spring 2007). Hong Kong, China: Report by the Hong Kong Bird 
Watching Society to the Agriculture, Fisheries and Conservation Department, Hong Kong Special Administrative Region Government.

Anon. (2012) Hunan cracking down on illegal bird hunting. China Daily (Accessed online from www.chinadaily.com.cn/china/201210/25/content_15847055.htm).

Askins, R. A. (2000) Restoring North America's birds: Lessons from landscape ecology. New Haven, USA: Yale University Press.

Azman, N. M., Abdul Latip, N. S., Mohd Sah, S. A., Md Akil, M. A. M., Shafie, N. J. and Khairuddin, N. L. (2011) Avian diversity and feeding guilds in a secondary forest, an oil palm plantation and a paddy field in riparian areas of the Kerian River basin, Perak, Malaysia. Trop. Life Sci. Res. 22: 45-64.

Bakewell, D. (2007) April 2nd, Bukit Mertajam rice-fields. (Accessed online from http:// digdeep1962.blogspot.com.au/2007/04/ april-2nd-bukit-mertajam-rice-fields.html).

Bakewell, D. (2013) Chuping, Perlis: 19 November 2013. (Accessed online from http://digdeep1962.wordpress.com/2013/ 11/22/chuping-perlis-19-november-2013/).

Bairlein, F. (1985) Body weights and fat deposition of Palaearctic passerine migrants in the central Sahara. Oecologia 66: 141-146.

Bairlein, F. and Schaub, M. (2009) Ringing and the study of mechanism of migration. Ring. Migr. 24: 162-168.

Bauer, S. and Hoye, B. J. (2014) Migratory animals couple biodiversity and ecosystem functioning worldwide. Science 344: 54-62.

Berthold, P. (1993) Bird migration: a general survey. Second Edition. Oxford, UK: Oxford University Press.

Bing, G-C., Choi, C-Y., Nam, H-Y., Park, J-G., Hong, G-P., Sung, J-K., Chae, H-Y and Choi, Y-B. (2012) Causes of mortality in birds at stopover islands. Korean J. Ornithol. 19: 23-31. (In Korean).

Bird, J. P., Lees, A. C., Chowdhury, S. U., Martin, R. and Haque, E. U. (2010) A survey of the Critically Endangered Spoon-billed Sandpiper Eurynorhynchus pygmeus in Bangladesh and key future research and conservation recommendations. Forktail 26: 1-8.

Bird Conservation Society of Thailand (2013) $12^{\text {th }}$ Thailand Bird Fair 2013. (Accessed online http:// www.bcst.or.th).
Birdfair Asia (2011) Asian bird fair. (Accessed online www.birdfair.asia/intro_committee. html).

BirdLife International (2012) BirdLife taxonomic checklist Version 5.1. (Accessed online from www.birdlife.org/datazone/info/taxonomy).

BirdLife International. (2013) BirdLife data zone. (Accessed online from www.birdlife. org/datazone/home).

Boer, B. W., Rothwell, D. R. and Ramsay, R. (1998) International environmental law in the Asia Pacific. London, UK: Kluwer Law International.

Boere, G. C. and Stroud, D. A. (2006) The flyway concept: what it is and what it isn't. Pp. 40-47 in G. C. Boere, C. A. Galbraith, and D. A. Stroud. eds. Waterbirds around the world. Edinburgh, UK: The Stationery Office.

Bolshakov, C. V. (2001) Results of the largescale study of nocturnal bird migration in the arid and mountainous zone of western Central Asia (Asia programme). Pp. 372393 in E. N. Kurochkin and I. I. Rakhimov, eds. Achievements and Problems of Ornithology of Northern Eurasia on the Border between the Centuries. Kazan, Russia: Magarif. (In Russian).

Both, C., Bouwhuis, S., Lessells, C. M. and Visser, M. E. (2006) Climate change and population decline in a long-distance migratory bird. Nature 441: 81-83.

Bradshaw, C. J. A., Warkentin, I. G. and Sodhi, N. S. (2009) Urgent preservation of boreal carbon stocks and biodiversity. Trends Ecol. Evol. 24: 541-548.

Brazil, M. (2009) Birds of East Asia. New Jersey, USA: Princeton University Press.

Bruderer, B. (1997) The study of bird migration by radar. Part 2: major achievements. Naturwissenschaften 84: 45-54.

Butler, R. (2009) Laos emerges as key source in Asia's illicit wildlife trade. Yale Environment 360. (Accessed online from www.e36o.yale.edu/content/feature. msp? id=2126).

Cao, L., Barter, M. and Lewthwaite, R. (2008a) The declining importance of the Fujian coast, China, for wintering waterbirds. Waterbirds 31: 645-650.

Cao, L., Barter, M. and Lei, G. (2008b) New Anatidae population estimate for eastern 
China: implication for current flyway estimates. Biol. Conserv. 141: 2301-2309.

Carey, G. J., Chalmers, M. L., Diskin, D. A., Kennerley, P. R., Leader, P. J., Leven, M. R., Lewthwaite, R. W., Melville, D. S., Turnbull, M. and Young, L. (2001) The avifauna of Hong Kong. Hong Kong, China: Hong Kong Bird Watching Society.

Chabot, A. A., Hobson, K. A., van Wilgenburg, S. L., McQuat, G. J. and Lougheed, S. C. (2012) Advances in linking wintering migrant birds to their breeding-ground origins using combined analyses of genetic and stable isotope markers. PLoS One 7(8): e43627.

Chan, S. (2004) Yellow-breasted Bunting Emberiza aureola. Birding ASIA 1: 16-17.

Chasen, F. N. (1932) Notes on some migratory birds from Pulau Pisang, west coast of Johore. Bull. Raffles Mus. 7: 3-7.

Chen, X., Li, B-L. and Lin, Z-S. (2003) The acceleration of succession for the restoration of the mixed-broadleaved Korean pine forests in northeast China. Forest Ecol. Manage. 177: 503-514.

Chen, S. (2009) Rudong to set up more clean power projects. China Daily. 22 September. (Accessed online at www.chinadaily.com.cn/ business/2009-09/22/content_8718773.htm).

Cheng, M. C., Lee, M. S., Ho, Y. H., Chyi, W. L. and Wang, C. H. (2010) Avian influenza monitoring in migrating birds in Taiwan during 1998-2007. Avian Dis. 54: 109-114.

Chernetsov, N. (2012) Passerine migration: stopovers and flight. Berlin, Germany: Springer.

China Ornithologists' Society (2008) China bird report. Beijing: China Ornithologists' Society.

Choi, C-Y. (2004). First record of the Spotted Bush Warbler (Bradypterus thoracicus davidi) in Korea. Korean J. Ornithol. 11: 95-99. (In Korean).

Choi, Y-S., Kim, S-H., Son, J-S., Kang, S-G., Hur, W-H and Han, S-H. (2013) Seasonal patterns of bird migration at a stopover site during the migratory period. Korean J. Ornithol. 20: 49-66. (In Korean).

Coates, B. J. and Bishop, K. D. (1997) A guide to the birds of Wallacea: Sulawesi, the Moluccas and Lesser Sunda Islands, Indonesia. Alderly, Australia: Dove Publications.

Coates, B. J. and Peckover, W. S. (2001) Birds of New Guinea and the Bismarck Archipelago: a photographic guide. Alderly, Australia: Dove Publications.

Convention on Migratory Species (2014) Parties to the Convention on the Conservation of Migratory Species of Wild Animals. (Accessed online from http://www.cms.int/ about/part_lst.htm).

Corlett, R. T. (2007) The impact of hunting on the mammalian fauna of tropical Asian forests. Biotropica 39: 292-303.

Corlett, R. T. (2009) The ecology of tropical East Asia. New York, USA: Oxford University Press.

Crosby, M. J. and Chan, S. (2006) Threatened waterbird species in eastern and southern Asia and actions needed for their conservation. Pp. 332-338 in G. C. Boere, C. A. Galbraith, and D. A. Stroud. eds. Waterbirds around the world. Edinburgh, UK: The Stationery Office.

Dale, S. and Hansen, K. (2013) Population decline in the Rustic Bunting Emberiza rustica in Norway. Ornis Fennica 90: 193-202.

Dänhardt, J., Green, M., Lindström, Å., Rundlöf, M. and Smith, H. G. (2010) Farmland as stopover habitat for migrating birds-effects of organic farming and landscape structure. Oikos 119: 1114-1125.

DeCandido, R., Nualsri, C., Allen, D. and Bildstein, K. L. (2004) Raptor migration at Chumphon, Thailand: a globally significant raptor watch site. Forktail 20: 49-54.

De Klemm, C. (1994) The problem of migratory species in international law. Pp. 67-77 in H. O. Bergensen, and G. Parmann, eds. Green globe yearbook of international cooperation on environment and development 1994. Oxford, UK: Oxford University Press.

Dinata, Y., Nugroho, A., Haidir, I. A. and Linkie, M. (2008) Camera trapping rare and threatened avifauna in west-central Sumatra. Bird Conserv. Internatn.18: 30-37.

Dingle, H. (2004) The Australo-Papuan bird migratory system: another consequence of Wallace's line. Emu 104: 95-108.

Dolnik, V. R., ed. (1987) Study of bird migration in the arid and mountainous regions of Middle Asia and Kazakhstan. Leningrad, USSR: Trudy Zoologicheskogo Instituta, Akademiya Nauk. (In Russian).

Dudgeon, D. (2000) Large-Scale Hydrological Changes in Tropical Asia: Prospects 
for Riverine Biodiversity. BioScience 50 : 793-806.

Du, M., Yu, Y. Wang, X., Lin, Z., Wu, C. and Wang, L. (2006) Preliminary study on the migration of passerines in autumn in Laotieshan Mountain, Liaoning province, China. Chinese J. Zool. 41: 74-79. (In Chinese).

East Asian-Australasian Flyway Partnership (2012) Partnership for the conservation of migratory waterbirds and the sustainable use of their habitats in the East Asian Australasian flyway. (Accessed online from http://www.eaaflyway.net/documents/key/ eaafp-partnership-doc-v13.pdf).

Ellis, D. H., Kepler, A. K. and Kepler, C. B. (1990) Evidence for a fall raptor migration pathway across the South China Sea. J. Raptor Res. 24: 12-18.

Emmanuel, B. and Yordan, K. (2013) First record of Japanese Paradise Flycatcher Terpsiphone atrocaudata for Java. Kukila: Indonesian J. Ornithol. 17: 30-32.

FAO (Food and Agriculture Organisation of the United Nations) (2005) Forest Resources Assessment 2005. Rome: FAO.

Feng, Y. (2012) Market trade is fuelling the killing of migratory birds in China. ChinaDialogue, 1o October. (Accessed online at https://www.chinadialogue.net/article/ show/single/en/5465-Market-trade-isfuelling-the-killing-of-migratory-birds-inNorthern-China).

Fitzherbert, E. B., Struebig, M. J., Morel, A., Danielsen, A., Brühl, C. A., Donald, P. F. and Phalan, B. (2008) How will oil palm expansion affect biodiversity? Trends Ecol. Evol. 23: 538-545.

Fransson, T., Kolehmainen, T. and Staav, R. (2007) Svensk ringmärkning. Pp. 19-25 in P. G. Bentz and A. Wirdheim, eds. Fågelåret 2006. Stockholm, Sweden: Sveriges Ornitologiska Förening. (In Swedish).

Fujioka, M., Lee, S. D., Kurechi, M. and Yoshida, H. (2010) Bird use of rice fields in Korea and Japan. Waterbirds 33: 8-29.

Gan, X., Choi, C., Wang, Y., Ma, Z., Chen, J. and Li, B. (2010) Alteration of habitat structure and food resources by invasive smooth cordgrass affect habitat use by wintering saltmarsh birds at Chongming Dongtan, East China. Auk 127: 317-327.
Germi, F., Young, G. S., Salim, A., Pangimangen, W. and Schellekens, M. (2009) Over-ocean raptor migration in a monsoon regime: spring and autumn 2007 on Sangihe, North Sulawesi, Indonesia. Forktail 25: 105-117.

Gibson-Hill, C. (1950) Birds recorded from Pulau Jarak, Malacca Strait. Bull. Raffles Mus. 23: 263-299.

Gilbert, M., Sokha, Chea, Joyner, P. H., Thomson, R. L. and Poole, C. (2012) Characterizing the trade of wild birds for merit release in Phnom Penh, Cambodia and associated risks to health and ecology. Biol. Conserv. 153: 10-16.

Gill, F. and Donsker, D. (2013) IOC world bird list (v. 3.5). (Accessed online at http//www. worldbirdnames.org).

Gluschenko, Y. N., Nechaev, V. A. and Gluschenko, V. P (2010) Birds of Primorsky Krai: Fauna, distribution, protection and bibliography. Far Eastern J. Ornithol. 1: 3-150. (In Russian).

Gluschenko, Y. N., Korobov, D. V. and Kalnitskaya, I. N. (2011) Paradise Flycatcher Terpsiphone paradisi of the KhankaRazdolnaya Plain: peculiarities of biology, morphology and population dynamics. Far Eastern J. Ornithol. 2: 8-12.

Gombobaatar, S., Brown, H. J., Sumiya, D., Tseveenmyadag, N., Boldbaatar, S., Baillie, J. E. M., Batbayar, G., Monks, E. M. and Stubbe, M. (2011) Summary conservation action plans for Mongolian birds. UK: Zoological Society of London, Mongolian Ornithological Society and National University of Mongolia. (Regional Red List Series Volume 8).

Greenberg, R. and Marra, P. R. (2005) Birds of two worlds: the ecology and evolution of migration. Baltimore, USA: The John Hopkins University Press.

Greenwood, J. J. D. (2007) Citizen, science and bird conservation. J. Ornithol. 148, Suppl. 1: 77-124.

Hahn, S., Bauer, S. and Liechti, F. (2009) The natural link between Europe and Africa 2.1 billion birds on migration. Oikos 118: 624-626.

Han, L-X., Huang, S-L, Yuan, Y. C. and Qiu, Y. L. (2007) Fall migration dynamics of birds on Fenghuang Mountain, Yunnan Province, China. Zool. Res. 28: 35-40. (In Chinese).

Harris, J. C. B., Yong, D. L., Sodhi, N. S., Subaraj, R., Fordham, D. and Brook, B. W. 
(2013) Changes in autumn arrival dates of long-distance migratory birds in Southeast Asia. Clim. Res. 57: 133-141.

Heim, W., Smirenski, S. M., Siegmund, A. and Eidam, F. (2012) Results of an autumnal bird ringing project at Muraviovka Park (Amur Region) in 2011. Avian Ecol. Behav. 21: 27-40.

Higuchi, H. and Morishita, E. (1999) Population declines of tropical migratory birds in Japan. Actinia 12: 51-59.

Higuchi, H., Shiu, H. J., Nakamura, H., Uematsu, A., Kuno, K., Saeki, M., Hotta, M., Tokita, K., Moriya, E., Morishita, E. and Tamura, M. (2005) Migration of Honeybuzzards Pernis apivorus based on satellite tracking. Ornithol. Sci. 4: 109-115.

Higuchi, H. (2012) Bird migration and the conservation of the global environment. J. Ornithol. 153 Suppl. 1: 3-14.

Higuchi, H. (2013) The journey of birds satellite tracking bird migration. Tokyo, Japan: SELC Co. Ltd.

Hirano, T. (1996) Changes in breeding avifauna during the past 25 years at Tomatsuriyama in Utsunomiya City, central Japan. Strix 14: 25-31.

Holmes, R. T. (2007) Understanding population change in migratory songbirds: long-term and experimental studies of Neotropical migrants in breeding and wintering areas. Ibis $149\left(\mathrm{~S}_{2}\right): 2-13$.

Hong, G-P., Bing, G-C., Choi, C-Y., Nam, H-Y., Won, I-J., Kim, S-J., Park, J-G. and Chae, H-Y. (2010) Migrating Black Drongo Dicrurus macrocercus feeding on passerines on a stopover island, Korea. J. Yamashina Inst. Ornithol. 41: 200-203.

Hüppop, O., Dierschke, J., Klaus-Michael, E., Fredrick, E. and Hill, R. (2006) Bird migration studies and potential collision risk with offshore wind turbines. Ibis 148 : 90-109.

Imanishi, S., Obata, Y., Murata, K., Edagawa, T., Iwasaki, K. and Ohmura, H. (2009) Differential timing of autumn migration of three species of leaf warblers Phylloscopus in Central Japan. J. Yamashina Inst. Ornithol. 40: 96-103. (In Japanese).

Iqbal, M., Ajiman, Noske, R. A. and Setiawan, D. (2014) Hunting of a very large aggregation of Eye-browed Thrushes Turdus obscurus in
Sumatra. Kukila: J. Indonesian Ornithol. 17: 68-71.

Irwin, D. E. and Irwin, J. H. (2005) Siberian migratory divides: the role of seasonal migration in speciation. Pp. 28-40 in R. Greenberg, and P. R. Marra, eds. Birds of two worlds: the ecology and evolution of migration. Baltimore, USA: The John Hopkins University Press.

IUCN-WCPA (2011) Protected areas in East Asia: Evaluating and strengthening implementation of the $C B D$ programme of work on protected areas and the East Asian regional action plan. Gland, Switzerland: IUCN.

Jeyarajasingham, A. and Pearson, A. (2012) Field guide to the birds of Peninsular Malaysia and Singapore. London, UK: Oxford University Press.

Johnson, M. D., Sherry, T. W., Holmes, R. T. and Marra, P. P. (2006) Assessing habitat quality for a migratory songbird wintering in natural and agricultural habitats. Conserv. Biol. 20: 1433-1444.

Karr, J. R. (1976) On the relative abundance of migrants from the north temperate zone in tropical habitats. Wilson Bull. 88: 433-458.

Kennedy, R. S., Gonzales, P. C., Dickinson, E. C., Miranda, H. and Fisher, T. H. (200o) A guide to the birds of the Philippines. New York, USA: Oxford University Press.

Kim, D-W. (2009) Breeding birds and bird migration pattern at Hataedo Island in Spring. Korean J. Ornithol. 16: 93-106. (In Korean).

Kim, D-W. and Yoo, J-C. (2010) Assessment of the stopover quality of Hongdo island for Passeriformes: study using the capturerecapture method. Korean J. Ornithol. 17: 179-185. (In Korean).

Kim, E-M., Choi, C-Y. and Kang, C-W. (2013) Causes of injury and mortality of Fairy Pitta Pitta nympha on Jeju Island, Republic of Korea. Forktail 29: 145-148.

Kirby, J. S. (2010) Review 2: Review of current knowledge of bird flyways, principal knowledge gaps and conservation priorities. Bonn, Germany: CMS Scientific Council: Flyway Working Group Reviews.

Kirby, J. S., Stattersfield, A. J., Butchart, S. H. M., Evans, M. I., Grimmett, R. F. A., Jones, V. R., O'Sullivan, J., Tucker, G. M. and Newton, I. (2008) Key conservation issues for migratory land- and waterbird species of the world's 
major flyways. Bird Conserv. Internatn. 18: 49-73.

Koike, S. and Higuchi, H. (2002) Long-term trends in the egg-laying date and clutch size of Red-cheeked Starlings Sturnia philippensis. Ibis 144: 150-152.

Komeda, S. and Ueki, Y. (2002) Long term monitoring of migratory birds at Otayama banding station (1973-1996). J. Yamashina Inst. Ornithol. 34: 96-111. (In Japanese).

Kondrashov, L. G. (2004) Russian Far East forest disturbances and socio-economic problems of restoration. Forest Ecol. Manage. 201: 65-74.

Knystautas, A. (1993) Collins guide to the birds of Russia. London, UK: HarperCollins.

Kuo, Y., Lin, D-L., Chuang, F-M., Lee, P-F. and Ding, T-S. (2013) Bird species migration ratio in East Asia, Australia and surrounding islands. Naturwissenschaften 100: 729-738.

Kuroda, N. (1971) Bird survey in the Ryu Kyus. Oct, 1970. J. Yamashina Inst. Ornithol. 6: 260-285. (In Japanese).

Kurosawa, R. and Askins, R. A. (2003) Effects of habitat fragmentation on birds in deciduous forests in Japan. Conserv. Biol. 17: 695-707.

Kwok, H. K. and Corlett, R. T. (2000) The bird communities of a natural secondary forest and a Lophostemon confertus plantation in Hong Kong, South China. Forest Ecol. Manage. 130: 227-234.

Kwon, Y-S., Kim, D-W., Lee, W-S., Kwon, I-K., Paek, W-K. and Yoo, J-C. (2007) Birds of Hongdo Island used as a breeding or stopover site in Korea. Korean J. Ornithol. 14: 51-60. (In Korean).

Laaksonen, T. and Lehikoinen, A. (2013) Population trends in boreal birds: continuing declines in agricultural, northern and longdistance migrant species. Biol. Conserv. 168: 99-107.

Leader, P. J. and Carey, G. J. (2012) Zappey's Flycatcher Cyanoptila cumatilis, a forgotten Chinese breeding endemic. Forktail 28: 121-128.

Li, H., Aide, M., Ma, Y., Liu, W. and Cao, M. (2007) Demand for rubber is causing the loss of high diversity rain forest in SW China. Biodivers. Conserv. 16: 1731-1745.

Li, J. (2012) Poaching of wild birds threaten some species. The South China Morning Post, 28 October. (Accessed online at http:// www.scmp.com/news/china/article/ 1071429/poaching-wild-birds-threatenssome-species).

Li, J. (2013) Yellow-breasted bunting 'endangered' as Guangdong diners refuse to stop eating it. The South China Morning Post, 23 November. (Accessed online at http:// www.scmp.com/news/china/article/ $1365285 /$ chinese-gourmands-drivemigratory-bird-endangered-list).

Li, X. Y., Liang, L., Gong, P., Liu, Y. and Liang, F. F. (2013) Bird watching in China reveals bird distribution changes. Chinese Sci. Bull.58: 649-656.

Liang, W., Cai, Y. and Yang, C. C. (2013) Extreme levels of hunting of birds in a remote village of Hainan Island, China. Bird Conserv. Internatn. 23: 45-52.

Lim, K. C. and Lim, K. S. (2009) State of Singapore's wild birds and bird habitats: $A$ review of the annual bird census, 1996-2005. Singapore: Nature Society (Singapore).

Linkie, M., Smith, R. J. and Leader-Williams, N. (2004) Mapping and predicting deforestation patterns in the lowlands of Sumatra. Biodivers. Conserv. 13: 1809-1818.

Liu, Y., Keller, I. and Heckel, G. (2011) Rangewide genetic population structure of common pochard (Aythya ferina): a potentially important vector of highly pathogenic avian influenza viruses. Ecol. Evol. 1: 529-545.

Lobkov, E. G. (2011) Kamchatka Wagtail Motacilla (alba) lugens (Gloger, 1829): variability, relationships with the Spectacled White Wagtail Motacilla alba ocularis (Swinhoe, 1860) and the taxonomic status. Far East. J. Orn. 2: 27-55.

Loss, S. R., Will, T., Loss, S. S. and Marra, P. P. (2014) Bird-building collisions in the United States: Estimates of annual mortality and species vulnerability. Condor 116: 8-23.

Low, B. W., Yong, D. L. and Chia, Y. S. A. (In prep) Bird-building collisions on the East Asian-Australasian Flyway: A preliminary study from Singapore.

Luo, S. T., Wu, Y. C., Chang, Q., Liu, Y., Yang, X. J., Zhang, Z. W. and Zou, F. S. (2014) Deep phylogeographic divergence of a migratory passerine in Himalayan and Siberian forests: the Red-flanked Bluetail (Tarsiger cyanurus) complex. Ecol. Evol. 4: 977-986.

Ma, Z. J., Li, B. and Chen, J. K. (2005) Study on the utilisation of stopover sites and 
migration strategies of migratory birds. Acta Ecol. Sinica. 25: 1404-1412. (In Chinese).

Ma, Z. J., Gan, X., Choi, C. Y., Jing, K., Tang, S., Li, C. and Chen, J. K. (2007) Wintering bird communities in newly formed wetland in the Yangtze River estuary. Ecol. Res. 22: 115-124.

Ma, Z. J., Cheng, Y., Wang, J. and Fu, X. (2013) The rapid development of birdwatching in mainland China: a new force for bird study and conservation. Bird Conserv. Internatn. 23: 259-269.

MacKinnon, J. and Phillipps, K. (1993) A field guide to the birds of Borneo, Sumatra, Java and Bali. Oxford, UK: Oxford University Press.

MacKinnon, J. and Phillipps, K. (2000) A field guide to the birds of China. Oxford, UK: Oxford University Press.

MacKinnon, J., Xie, Y., Lysenko, I., Chape, S., May, I. and Brown, C. (2005) GIS Assessment of the status of protected areas in East Asia. Cambridge, UK and Gland, Switzerland: UNEP-WCMC and IUCN.

Mahood, S. P., Eaton, J. A. and Leader, P. J. (2013a) Second record of Rufous-headed Robin Luscinia ruficeps outside its breeding range and a description of its first-winter plumage. Birding Asia 19: 43-47.

Mahood, S. P., Delonglée, S., Klingel, F., Wicker, F. and Robson, C. (2013b) The status of Brown-chested Jungle Flycatcher Rhinomyias brunneata in Vietnam. Forktail 29: 20-26.

Malhi, Y., Adu-Bredu, S., Asare, R. A., Lewis, S. L. and Mayaux, P. (2013) African rainforests: past, present and future. Philos. T. R. Soc. B 368: 20120312.

Marra, P. P., Hobson, K. A. and Holmes, R. T. (1998) Linking winter and summer events in a migratory bird using stable carbon isotopes. Science 282: 1884-1886.

McClure, H. E. (1967) The composition of mixed species flocks in lowland and submontane forests of Malaya. Wilson Bull. 79: 131-154.

McClure, H. E. (1974) Migration and survival of the birds of Asia. Bangkok, Thailand: Applied Scientific Research Corporation of Thailand.

McClure, H. E. and Chaiyaphun, S. (1971) The sale of birds at the Bangkok "Sunday Market" Thailand. Nat. Hist. Bull. Siam Soc. 24: 41-78.
McClure, H. E. and Ratanaworabhan, N. (1973) Some ectoparasites of the birds of Asia. Bangkok, Thailand: Applied Scientific Research Corporation of Thailand.

McKinnon, E. A., Fraser, K. C. and Stutchbury, B. J. M. (2013) New discoveries in landbird migration using geolocators, and a flight plan for the future. Auk 130: 211-222.

McCulloch, M. N., Tucker, G. M. and Baillie, S. R. (1992) The hunting of migratory birds in Europe: a ringing recovery analysis. Ibis 134 : $55-65$.

Medway, L. (1970) A ringing study of the migratory brown shrike in West Malaysia. Ibis 112: 184-198.

Miettinen, J., Shi, C. and Liew, S. C. (2010) Deforestation rates in insular Southeast Asia between 2000 and 2010. Glob. Change Biol. 17: 2261-2270.

Mizuta, T., Utsunomiya, H., Torikai, H. and Abe, Y. (2009) A record of Gray's Grasshopper Warbler found on a ferry sailing from Kyushu to Amami-Oshima Island. J. Yamashina Inst. Ornithol. 41: 65-68. (In Japanese).

Moores, N. (2012) The distribution, abundance and conservation of avian biodiversity in Yellow Sea habitats in the Republic of Korea. Unpublished $\mathrm{PhD}$ thesis. University of Newcastle.

Moores, N. (2013) "Forest Bird Workshop", March 21st-23rd, Seoul, ROK. (Accessed online at http://www.birdskoreablog.org/ ? $\mathrm{p}=7999)$.

Moreau, R. E. (1972) The Palearctic-African bird migration systems. London, UK: Academic Press.

Morel, G. J. and Morel, M-Y. (1992) Habitat use by Palearctic migrant passerine birds in West Africa. Ibis 134 Suppl. 1: 83-88.

Nakamura, T. and Ishizawa, J. (1965) Studies on the migration of Locustella fasciolata II. Duration of migration, flock formation and physiology. J. Yamashina Inst. Ornithol. 4: 217-220. (In Japanese).

Nam, H-Y., Choi, C-Y., Park, J-G., Hong, G-P., Won, I-J., Kim, S-J. Bing, G-C. and Chae, H-Y. (2011) Protandrous migration and variation in morphological characters in Emberiza buntings at an East Asian stopover site. Ibis 153: 494-501. 
Nash, S. V. (1993) Sold for a song: the trade in Southeast Asian non-CITES birds. Cambridge, UK: Traffic International.

Newton, I. (2004) Population limitation in migrants. Ibis 146: 197-226.

Newton, I. (2007) The migration ecology of birds. London, UK: Academic Press.

Nisbet, I. C. T. and Medway, L. (1974) Dispersion, population ecology and migration of Eastern Great Reed Warblers Acrocephalus orientalis wintering in Malaysia. Ibis 114: 451-494.

Norris, D. R., Marra, P. P., Kyser, T. K., Sherry, T. W. and Ratcliffe, L. M. (2004) Tropical winter habitat limits reproductive success on the temperate breeding grounds in a migratory bird. Proc. R. Soc. B. Biol. Sci. 271: 59-64.

Ogden, L. J. E. (1996) Collision course: the hazards of lighted structures and windows to migrating birds. Toronto, Canada: World Wildlife Fund Canada and the Fatal Light Awareness Program.

Ornat, A. L. and Greenberg, R. (1990) Sexual segregation by habitat in migratory warblers in Quintana Roo, Mexico. Auk 107: 539-543.

Ozaki, K. (2008) Monitoring and banding activities in Japan. Pp. 53-59 in: Proceeding of the $2^{\text {nd }}$ International Symposium on Migratory Birds. Changwon: Monitoring Climate Changes, Migratory Birds and Wetlands in Stopover Islands.

Park, J-G., Hong, G-P. and Chae, H-Y. (2008) Morphological traits and migratory patterns of Narcissus Flycatcher (Ficedula narcissina) in Korea. Korean J. Ornithol. 15: 1-15. (In Korean).

Pearson, D. J. and Lack, P. C. (1992) Migration patterns and habitat use by passerines and near-passerine migrant birds in eastern Africa. Ibis 134 Suppl.: 89-98.

Pronkevich, V. V., Averin, A. A., Svetlakov, A. N., Mannanov, I. A., Roslakov, A. G., Tagirova, V. T. and Kapitonova, L. V. (2007) Studies of bird migrations in the Middle Amur lowland by capturing birds with mistnets. Pp. 66-67 in Third International Conference on Migratory Birds of the Pacific North. Yakutsk, Russia: Publishing House of the Yakutia Science Center, Siberian Branch of the Russian Academy of Science. (In Russian).

Pronkevich, V. V. (2011) Spring migration of birds in the Lower Ussuri basin in 2005. Amurian Zool. J. 3: 64-77. (In Russian).
Rappole, J. H., Morton, E. S., Lovejoy, T. E. and Ruos, J. S. (1983) Nearctic avian migrants in the Neotropics. Washington DC, USA: US Fish and Wildlife Service.

Rappole, J. H., King, D. I. and Diez, J. (2003) Winter versus breeding habitat limitation for an endangered avian migrant. Ecol. Appl. 13: 735-742.

Rasmussen, P. R. and Anderton, J. (2005) Birds of South Asia: The Ripley guide. Volume 2. Barcelona, Spain: Lynx Edicions.

Rich, C. and Longcore, T. eds. (2005) Ecological consequences of artificial night lighting. Washington DC, USA: Island Press.

Robson, C. (2000) A guide to the birds of Southeast Asia. New Jersey, USA: Princeton University Press.

Round, P. D. (2010) An analysis of records of three passage migrants in Thailand: Tiger Shrike Lanius tigrinus, Yellow-rumped Flycatcher Ficedula zanthopygia and Mugimaki Flycatcher F. mugimaki. Forktail 26: 24-30.

Round, P. D. and Rumsey, S. J. (2003) Habitat use, moult and biometrics in the Manchurian Reed Warbler Acrocephalus tangorum wintering in Thailand. Ringing and Migr. 21: 215-221.

Round, P. D. and Fisher, T. H. (2009) Records of Black-browed Reed Warbler Acrocephalus bistrigiceps from Luzon, Philippines. Forktail 25: 159-160.

Round, P. D., Hansson, B., Pearson, D. J., Kennerley, P. R. and Bensch, S. (2007) Lost and found: the enigmatic Large-billed Reed Warbler Acrocephalus orinus rediscovered after 139 years. J. Avian Biol. 38: 133-138.

Round, P. D., Pierce, A. J., Sankamethawee, W. and Gale, G. A. (2011) The avifauna of the Mo Singto forest dynamics plot, Khao Yai National Park, Thailand. Nat. Hist. Bull. Siam. Soc. 57: 57-80.

Ruth, J. M., Diehl, R. H. and Felix, R. K. (2012) Migrating birds' use of stopover habitat in the southwestern United States. Condor 114: 698-710.

Sabah Wildlife Department (2004) Protected species. (Accessed online http://www.wildlife. sabah.gov.my/).

Salovarov, V. O. and Kuznetsova, D. V. (2006) Impact of coal mining on bird distribution in Upper Angara region. Biol. Bull. 33: 248-251. 
Sam, V. (1999) Survey for Sarus Crane and other endangered bird species in southern Kampong Thom province, Cambodia. Bedford, UK: Unpublished report to the Oriental Bird Club.

Sands, P. (2003) Principles of international environmental law. Cambridge, UK: Cambridge University Press.

Sanderson, F. J., Donald, P. F., Pain, D. J., Burfield, I. J. and van Bommel, F. P. J. (2006) Longterm population declines in Afro-Palearctic migrant birds. Biol. Conserv. 131: 93-105.

Severinghaus, L. L. (1996) Territory strategy of the migratory Brown Shrike Lanius cristatus. Ibis 138: 460-475.

Severinghaus, L. L. and Chi, L. (1999) Prayer animal release in Taiwan. Biol. Conserv. 89: 301-304.

Sheehy, J., Taylor, C. M. and Norris, D. R. (2011) The importance of stopover habitat for developing effective conservation strategies for migratory animals. J. Ornithol. 152 Suppl. 1: 161-168.

Shepherd, C. R., Sukumaran, J. and Wich, S. A. (2004) Open season: an analysis of the pet trade in Medan, Sumatra 1997-2001. Kuala Lumpur, Malaysia: TRAFFIC Southeast Asia.

Shepherd, C. R. (2006) The bird trade in Medan, North Sumatra: an overview. BirdingASIA 5: 16-24.

Sherry, T. W. and Holmes, R. T. (1995) Summer versus winter limitation of populations: What are the issues and what is the evidence? Pp. 85-120 in T. E. Martin, and D. M. Finch, eds. Ecology and management of Neotropical migratory birds: a synthesis and review of critical issues. New York, USA: Oxford University Press.

Sherry, T. W. and Holmes, R. T. (1996) Winter habitat quality, population limitation, and conservation of Neotropical-Nearctic migrant birds. Ecology 77: 36-48.

Shiu, H-J. and Lee, P-F. (2003) Seasonal variation in bird species richness along elevational gradients in Taiwan. Acta Zool. Taiwan. 14: 1-21.

Shiu, H-J., Tokita, K., Morishita, E., Hiraoka, E., Wu, Y. Y., Nakamura, H. and Higuchi, H. (2006) Route and site fidelity of two migratory raptors: Grey-faced buzzard Butastur indicus and Honey buzzards Pernis apivorus. Ornithol. Sci. 5: 151-156.
Simpson, D. M. (1983a) Autumn migration of landbirds off north Borneo in 1981. Sea Swallow 32: 48-53.

Simpson, D. M. (1983b) Birds seen at the Tembungo gas flare, North Borneo during the development of Typhoon 'Clara'. Sea Swallow 32: 82-83.

Sivay, M. V., Sayfutdinova, S. G., Sharshov, K. A., Alekseev, A., Yurlov, A. K., Runstadler, J. and Shestopalov, A. M. (2012) Surveillance of Influenza A virus in wild birds in the Asian portion of Russia in 2008. Avian Dis. 56: 456-463.

Sodhi, N. S. and Sharp, I. (2006) Winged invaders: Pest birds of the Asia-Pacific. Singapore: Singapore National Publishers.

Sodhi, N. S., Posa, M. R. C., Lee, T. M., Bickford, D., Koh, L. P. and Brook, B. W. (2010) The state and conservation of Southeast Asian biodiversity. Biodivers. Conserv. 19: 317-328.

Song, G., Alström, P., Zhang, Y., Gao, X., Gong, H., Holt, P. I., Quan, Q., Yin, Z. and Lei, F. (2013) Rediscovery of an enigmatic Chinese passerine, the Blackthroat Calliope obscura: plumage, vocalizations, distribution, habitat choice, nesting and conservation. J. Ornithol. 155:347-356.

Stafford, J. D., Kaminski, R. M. and Reinecke, K. J. (2010) Avian foods, foraging and habitat conservation in world rice fields. Waterbirds 33: 133-150.

Sutherland, W. J. (1996) Predicting the consequences of habitat loss for migratory populations. Proc. R. Soc. B. Biol. Sci. 263: 1325-1327.

Tordoff, A. W., Appleton, T., Eames, J. C., Eberhardt, K., Hla, H., Thwin, K. M. M., Zaw, S. M., Moses, S. and Aung, S. M. (2007) Avifaunal surveys in the lowlands of Kachin State, Myanmar, 2003-2005. Nat. Hist. Bull. Siam Soc. 55: 235-306.

Tang, W., Deng, X. J. and Wang, B. (2003) Research on migratory birds via Daniaoao of Longhui County in Hunan. J. Hunan Polytechn. Environ. Biol. 9: 29-33. (In Chinese).

Townsend, T. (2012) Illegal mist nets in China. (Accessed online from http://birdingbeijing. com/2012/o9/28/illegal-mist-nets-inchina/).

Townsend, T. (2013) Beijing's wild bird markets. (Accessed online from http://birdingbeijing. 
com/2013/11/13/beijings-wild-birdmarkets/).

U.S. Fish and Wildlife Service (2014) US-Japan migratory birds convention. (Accessed online from http://www.fws.gov/international/ wildlife-without-borders/east-asia/usjapan-migratory-birds-convention.html).

Valencia, M. J. (2007) The East China Sea dispute: context, claims, issues, and possible solutions. Asian Perspective 31: 127-167.

Valchuk, O., Yuasa, S. and Morosova, E. (2005) Migration of Rustic Bunting Emberiza rustica at the eastern edge of Asia. Alauda 73:323.

Valchuk, O. and Huettmann, F. (2006) Morphometric data from avian influenza sampling in the southern Primorye Region, fall 2006. (Digital dataset available online from https://scholarworks.alaska.edu/ bitstream/handle/11122/1012/SeaofOk hotskAvianInfluenzaSampling2006AI_ Primorye_vers $3 . x m l . h t m l$ ? sequence $=91$ ).

Vickery, J. A., Ewing, S. R., Smith, K. W., Pain, D. J., Bairlein, F., Skorpilova, J. and Gregory, R. D. (2014) The decline of AfroPalaearctic migrants and an assessment of potential causes. Ibis 156: 1-22.

Wang, N., Zhang, Y. and Zheng, G. (2006a) Home ranges and habitat vegetation characters in breeding season of Narcissus Flycatcher and Yellow-rumped Flycatcher. J. Beijing Norm. Univ. (Nat. Sci.) 42: 295-299. (In Chinese).

Wang, Y., Finch, D. M., Moore, F. R. and Kelly, J. F. (1998) Stopover ecology and habitat use of migratory Wilson's Warblers. Auk 115: 829-841.

Wang, Y., Chang, J. C., Moore, F. R., Su, L., Cui, L. and Yang, X. (2006b) Stopover ecology of Red-flanked Bush Robin (Tarsiger cyanurus) at Maoershan, northeast China. Acta Ecol. Sinica 26: 638-646. (In Chinese).

Wells, D. R. (2006) Birds of the Thai-Malay Peninsula. Volume 2. London, UK: Academic Press.

Won, I-J., Park, J-G., Hong, G-P., Kim, S-J., Choi, C-Y., Bing, G-C., Nam, H-Y. and Chae, H-Y. (2010) Migratory patterns of birds on Hongdo and Heuksando Islands. J. Nat. Park Res. 1: 29-44. (In Korean).

Won, P-O., Woo, H-C., Ham, K-W. and Yoon, M-B. (1966) Seasonal distribution and ecology of migrant bird populations by mistnetting and banding in Korea (I). J. Yamashina Inst. Ornithol. 8: 405-444. (In Korean).

Wood, C., Sullivan, B., Iliff, M., Fink, D. and Kelling, S. (2011) eBird: Engaging birders in science and conservation. PLoS Biol. 9: e1001220.

Wong, T.S. (2014) A snap shot of caged birds in Balikpapan, Indonesian Borneo. (Accessed online from http://borneobirds.blogspot.com. au/2014/05/a-snap-shot-of-caged-birds-in. html).

Xiao, F. Z., Li, M. J. and Jiang, Y. (2005) The study of migratory birds passage in Suichuan. Jiangxi For. Sci. Technol. 3: 8-10. (In Chinese).

Xie, W. and Gao, S. (2013) Invasive Spartina alterniflora-induced factors affecting distribution in coastal salt marsh, China. Acta Oceanol. Sinica 32: 81-88.

Yamamoto, Y. and Seto, N. (1997) Decrease of summer visiting birds in Yamaguchi Prefecture analysed from records of regular birding events. Strix 15: 15-23.

Yamaura, Y., Amano, T., Koizumi, T., Mitsuda, Y., Taki, H. and Okabe, K. (2009) Does land-use change affect biodiversity dynamics at a macroecological scale? A case study of birds over the past 20 years in Japan. Anim. Conserv. 12: 110-119.

Yanagawa, H. and Shibuya, T. (1998) Causes of wild bird mortality in eastern Hokkaido III Bird-window collisions. Res. Bull. Obihiro Univ, Nat. Sci. 20: 253-258. (In Japanese).

Yang, T., Yang, X., Wang, Z., Liu, L., An, Q., Zhang, H., Li, G. and Shi, W. (2009) Influencing factors of birds captured at night in Ailao Mountain, Xinping County, Yunnan Province. Zool. Res. 30: 411-417. (In Chinese).

Yap, F., Yong, D. L., Low, B. W., Lim, K. K., Foley, C., Cros, E. and Rheindt, F. E. (2014) First wintering record of the Sakhalin Leaf Warbler Phylloscopus borealoides in SouthEast Asia, with notes on vocalisations. BirdingAsia 21: 76-81.

Yong, D. L. (2013) Bidadari now. Nature Watch 21: 3-9.

Yong, D. L., Lim, K. C. and Lee, T. K. (2013) Naturalist's guide to the birds of Singapore. Oxford, UK: John Beaufoy Publishing Ltd.

Yong, D. L. and Liu, Y. (In press) Passage of the brown-chested jungle-flycatcher in 
Singapore, with notes on wintering status in Southeast Asia. Forktail.

Yoshii, M., Sato, F., Ozaki, K., Shigeta, Y., Komeda, S., Yoshiyasu, K. and Mitamura, A. (1989) Japanese bird banding now and past. J. Yamashina Inst. Ornithol. 21: 309-325. (In Japanese).

Yu, Y. T., Chan, K. T., Fong, H. H. N. and Tse, I. W. L. (2013) International Black-faced Spoonbill census 2013. Hong Kong, China:
Black-faced Spoonbill Research Group, The Hong Kong Bird Watching Society.

Zhao, X. M. (2006) Bird migration and bird flu in the mainland of China. Beijing, China: China Forestry Publishing House. (In Chinese).

Zhou, D., Fung, T. and Chu, L. M. (2012) Avian community structure of urban parks in developed and new growth areas: A landscape-scale study in Southeast Asia. Landscape Urban Plan. 108: 91-102.

\section{DING LI YONG*}

Fenner School of Environmental and Society, The Australian National University, Linnaeus Way, Acton ACT 2601, Australia.

\section{YANG LIU*}

State Key Laboratory of Biocontrol and College of Ecology and Evolution, Sun Yat-Sen University, No. 135 Xingangxi Road, Guangzhou 510275, Peoples' Republic of China.

\section{BING WEN LOW, DING LI YONG*}

Southeast Asian Biodiversity Society, 504 Choa Chu Kang Street 51, \#01-173, S (680504), Singapore.

\section{CARMELA P. ESPAÑOLA}

Institute of Biology, College of Science, University of the Philippines, Diliman, Quezon City 1101, Metro Manila, Philippines.

\section{CHANG-YONG CHOI}

Research Institute for Agriculture and Life Sciences, Seoul National University, Seoul 151-921, South Korea.

\section{KAZUTO KAWAKAMI}

Forestry and Forest Products Research Institute, I Matsunosato, Tsukuba, Ibaraki 305-8687, Japan.

*Author for correspondence: e-mail:ding.li@anu.edu.au

${ }^{*}$ These authors contributed equally to this work

Received 25 November 2013; revision accepted 17 July 2014 